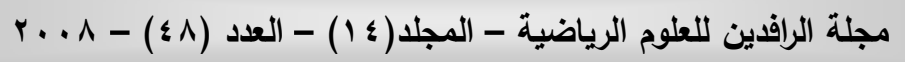

أثر التوقف عن التدريب في عدد من عناصر اللياقة البذنية الخاصة ويعض المهارات الأساسية بلعبة الريشة الطائرة

الباحث

م.م عمار محمد خليل

كلية التربية الرياضية

جامعة الموصل

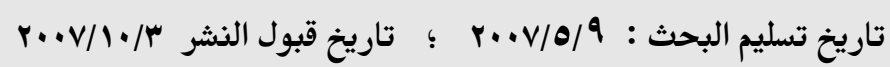

\title{
الملخص
}

إن من أهم المبادئ الأساسية التي يعتمد عليها التدريب الرياضي للفعاليات بشكل عام

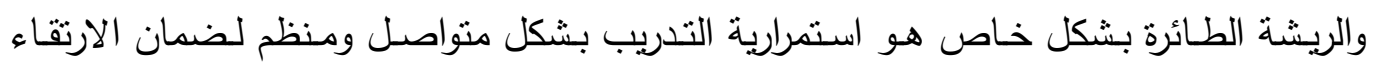

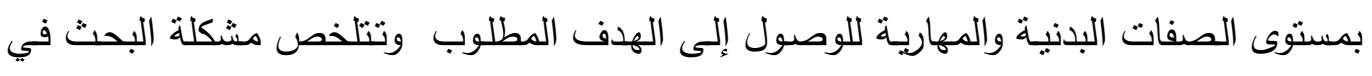

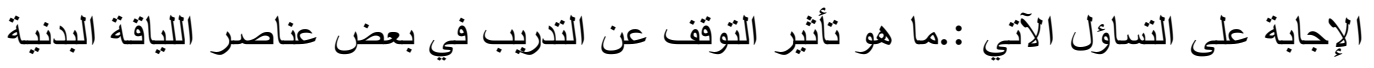

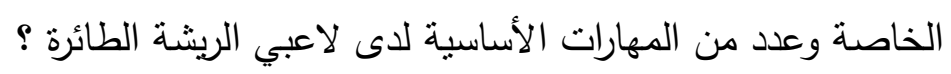

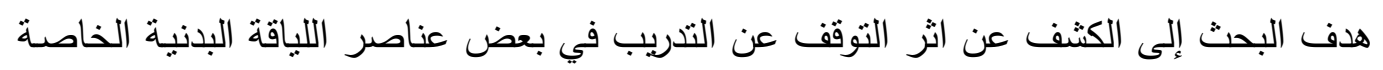

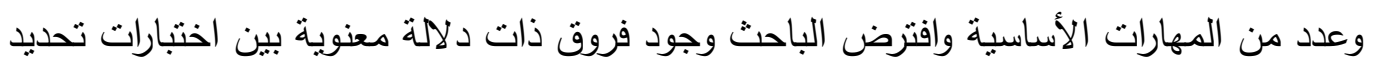

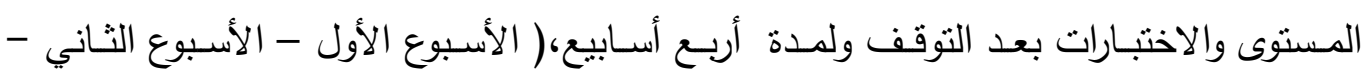

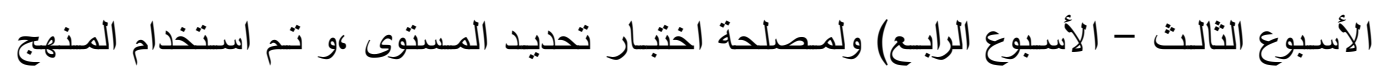

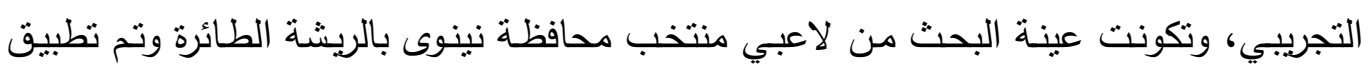

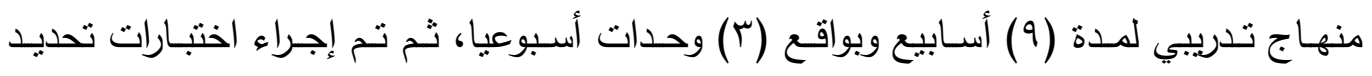

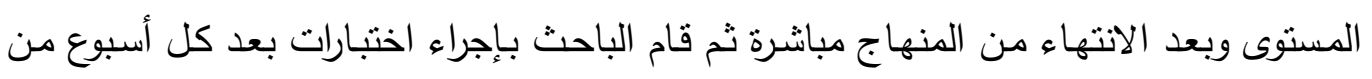
النوقف واستتنج الباحث ما يأني: 1 - أحدث التوقف عن التدريب لمدة ( أسبوع - أسبوعان - ثلاثة أسابيع - أربعة أسابيع )

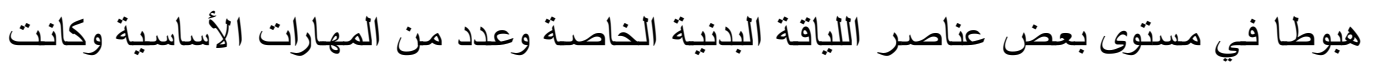

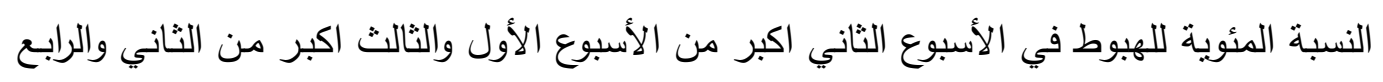
اكبر من الثالث . r - كانت النسبة المئويـة لهبوط بعض عناصر اللياقة البدنية وهي (القوة المميزة بالسرعة 


$$
\begin{aligned}
& \text { للذراعين والقوة المميزة بالسرعة للرجلين و المرونـة ) أسرع من النسبة المئويـة لهبوط الرشاقة } \\
& \text { لكأسابيع الأربعة . } \\
& \text { r - كانت النسبة المئوية لهبوط المهارات الأساسية ( الإرسال الواطئ القصير والإرسال العالي } \\
& \text { الطويل والكبس الساحق ) منقاربة للأسابيع الأربعة . } \\
& \text { ع- كانت النسبة المئوية لهبوط القوة المميزة بالسرعة للذراعين اكبر من باقي عناصر اللياقة لإنة }
\end{aligned}
$$

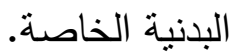

\section{Abstract \\ The effect of stop-training on some elements of special physical health and some basic skills of badminton}

Ammar M. Khaleel

game

Assistant lecturer

College of physical education- Mosul university

One of the most important principles of the athletic training science for activities in general and especially badminton game is the continuity of training with constant rate to ensure rising in physical and skill properties to reach the target.

The main problem of the present work is to answer the question: "what is the effect of training stop on some elements of special physical health and some basic skills at badminton players". The researcher assumed that their will be a significant differences between the test used to measure the level and the other tests after stopping training, with 4weeks period, assuming that better results obtained from the first one. The experimental method adopted, with a sample from Nineveh's Olympic team players of badminton game. The main training program was used for 9-weeks period with average of 3 units weekly. After the main training program, the test of measuring level performed directly. Then the researcher does the tests after each week of stopping training. The work give some conclusions summarized as:

1. Stopping training for one to four weeks caused decreasing in level of some special physical properties and some of basic skills with a percentage of decreasing for the second week greater than the first 
and third weeks and the third week give more decreasing than the forth week.

2. The decreasing level in some physical properties (Force with speed properties for arms, force with speed properties for legs, and flexibility) are faster than the percentage of fitness for the four weeks.

3. The decreasing percentage of the basic skills (low short service, high long service, smash ) are approximately the same for the four weeks.

1. The $\mathrm{b}$ decreasing percentage of the force with speed properties for the arms are relatively greater than the other elements of the physical properties

\section{1-التعريف بالبحث: \\ 1-1 المقدمة وأهمية البحث:}

إن من أهم المبادئ الأساسية التي يعتمد عليها التدريب الرياضي هو الاستمرار في

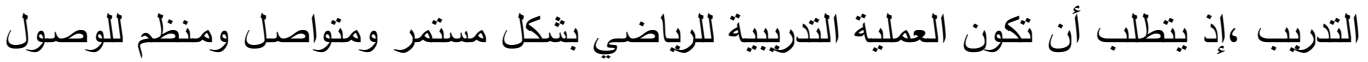

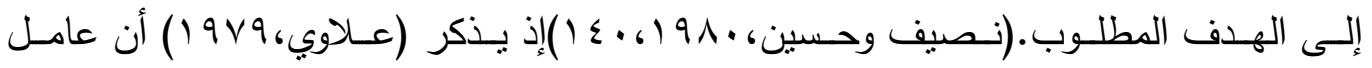
الاستمرارية في التدريب الرياضي يعد من أهم العوامل اللازمة لضمان الارتفاع بمستوى الصفات

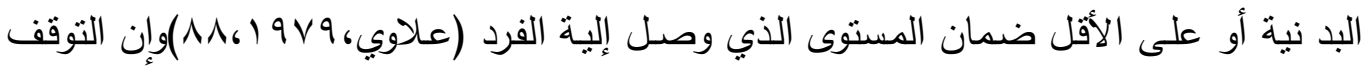
عن التدريب لفترة زمنية معينة من شانه أن يضعف في قيمة عناصر اللياقة البدنية والمهارية

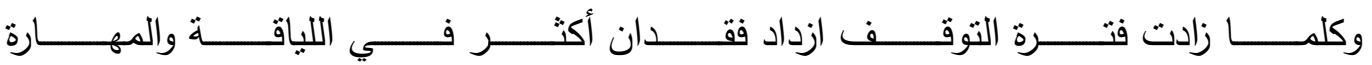

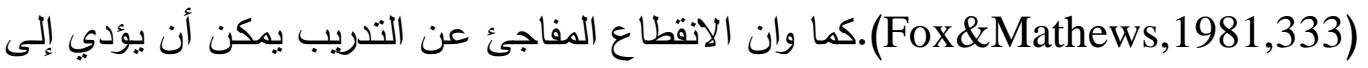
الإخلال بحالة الرياضي الصحية وتتشأ عن ذلك صعوبات عند معاودة التدريب. ولعبة الريشة الطائرة ومـا وصلت إليهه من تطور في مستوى الأداء واللعب شـأنها شـان كل الإنل

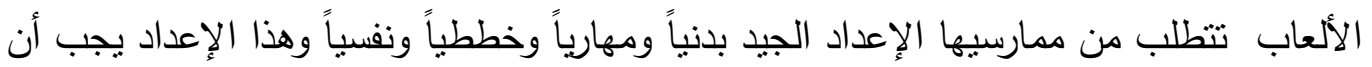

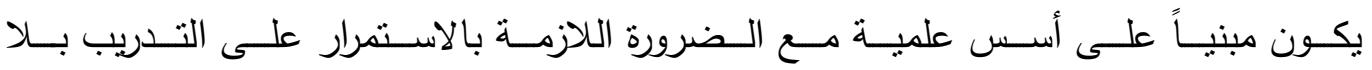

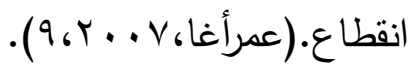

من خلال ما تقدم تبرز أهمية البحث في معرفة الحقائق العلمية الناتجة من تأثثر التوقف عن

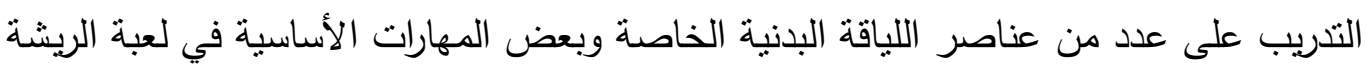
الطائرة من أجل تزويد المعنيين(مدربين ولاعبين ومدرسين وباحثين..) في رياضة الريشة الطائرة 
بالمعلومات العلميـة والدلالات عن اثر التوقف عن التدريب لكي تكون عوناً لهم عند وضـع التها المناهج التدربيية أو إجراء بحوث تتعلق باللاعبين المتوقفين عن التدريب إرادياً أو قسرياً من أجل الجل

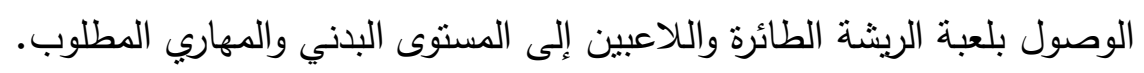

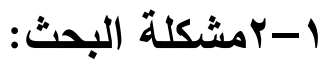

إن لعبة الريشة الطائرة تختلف في طبيعة أداءها عن باقي ألعاب المضرب وكل الألعاب

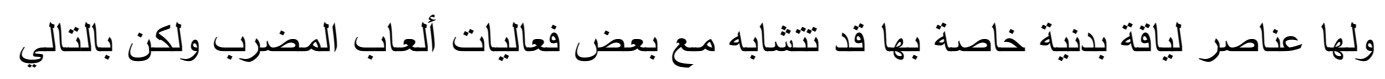

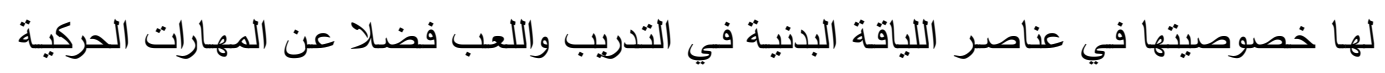

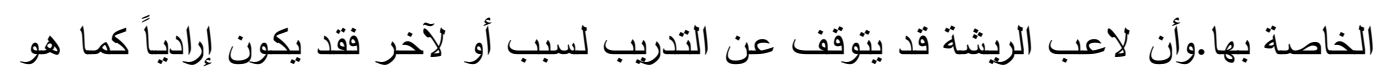

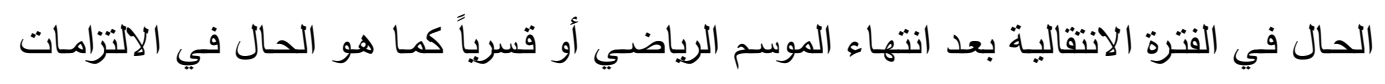

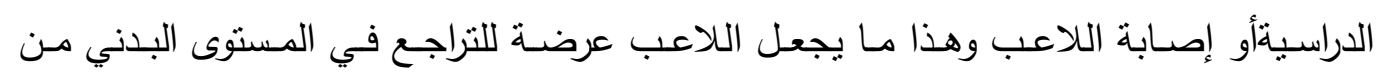

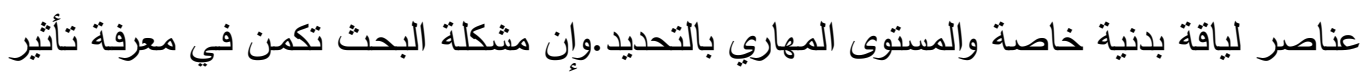
هذا الانقطاع عن الندريب على مستوى اللاعب البدني والمهاري.

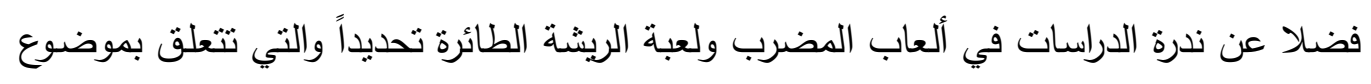

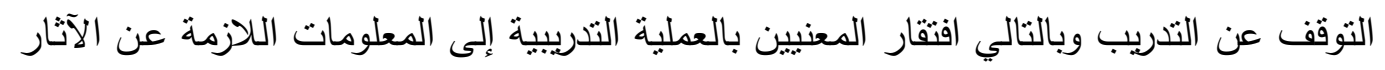
الناجمة عن هذا النوقف في مستوى عناصر اللياقة البدنية الخاصة والأداء المهاري.

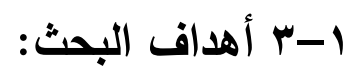

*/الكشف عن أثر التوقف عن التدريب لمدة (أسبوع واحد وأسبوعين و ثناثة أسـابيع وأربعة أسابيع)في عدد من عناصر اللباقة البدنية الخاصة لاى لاعبي الريشة الطائرة.

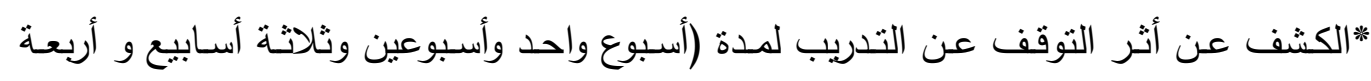
أسابيع)في بعض المهارات الأساسية لدى لاعبي الريثة الطائرة.

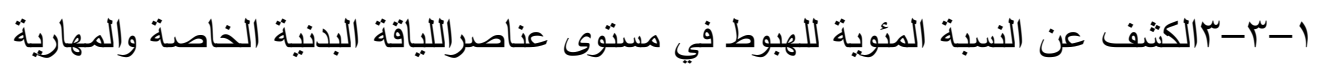

\section{1- إن فروض البحث:}

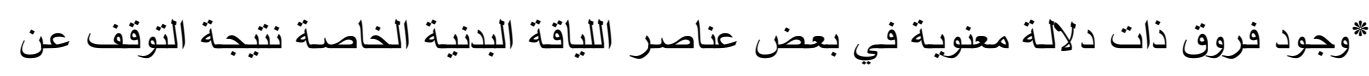
التدريب ما بين تحديد المستوى وبعد التوقف لمدة(أسبوع واحد-أسبوعين - ثلاثة أسابيع -أربعة فئة (أسابيع).

"وجود فروق ذات دلالة معنوية في بعض المهارات الأساسية نتيجة التوقف عن التدريب ما 
بين تحديد المستوى وبعد التوقف لـ (أسبوع واحد-أسبوعين - ثلاثة أسابيع-أربعة أسابيع). *النسبة المئوية للهبوط في مستوى عناصر اللياقة البدنية والمهارية تزداد كلما زادت فترة النوقف عن التدريب

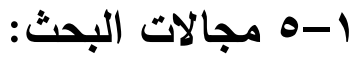

*المجال البشري:لاعبو منتخب محافظة نينوى بلعبة الريشة الطائرة */المجال المكاني:القاعة الرياضية لفرع الألعاب الفردية/كلية التربية الرياضية /جامعة الموصل الريل

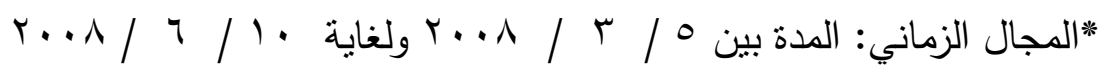
r-الدراسات النظرية والدراسات المشابهة: بانة

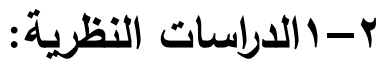

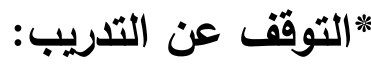

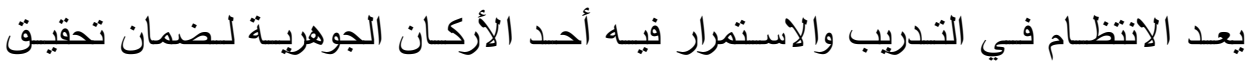

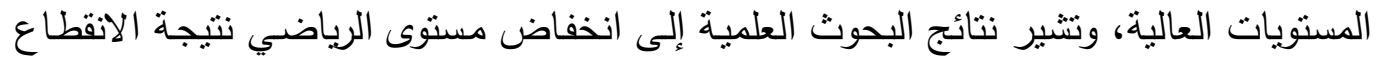

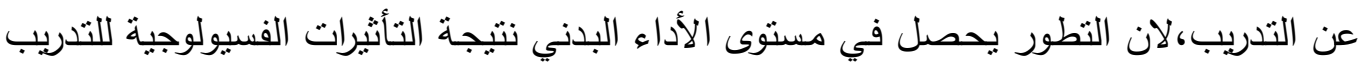

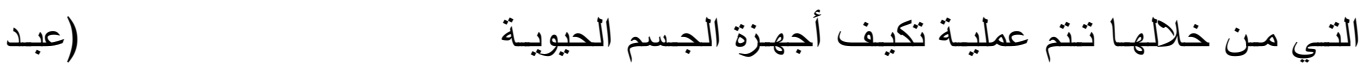
الحسين وآخران،0 . . ץ، ام)،ويعد مبدأ الاستمرارية في التدريب من القواعد المهمة لديمومـة

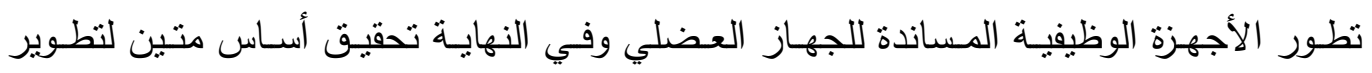
المستوى الرياضي من خلال الارتقاء بمستوى أجهزة الجسم الوظيفية والبدنية و المهارية،لذا فإن

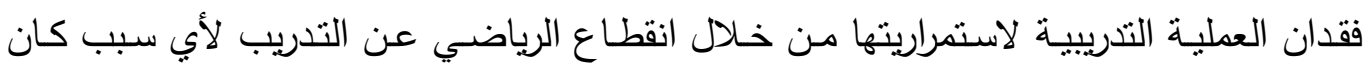

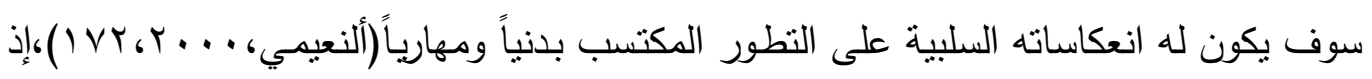
يؤكدان (Mirkin\&Hoffman,1978)بهذا الخصوص أن التوقف عن التدريب لفترة تتراوح مابين (r-ـ) أسابيع تكفي لفقدان جميع ما تم الحصول علية من تطورات في اللياقة البدنية

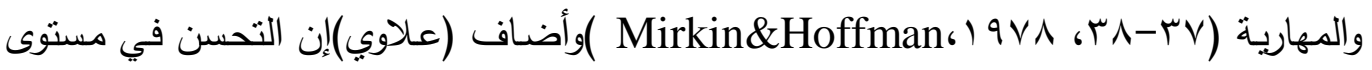
الفرد الناتج عن ممارسة النشاط البدني والمهاري هو تحسن قابل للزيادة والنقصان ففي حالة

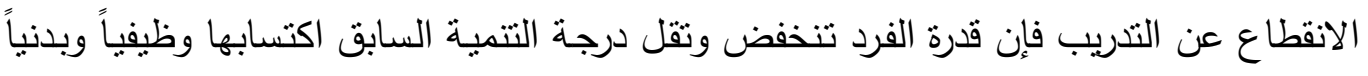

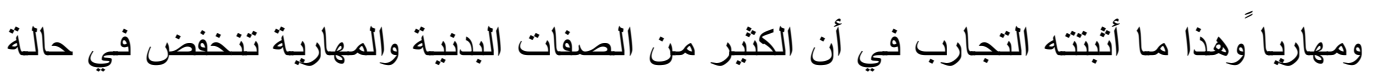

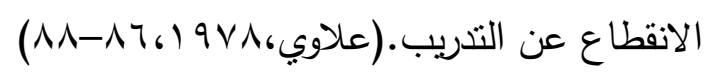
*اللياقة البلنية الخاصة بلعبة الريشة الطائرة: 


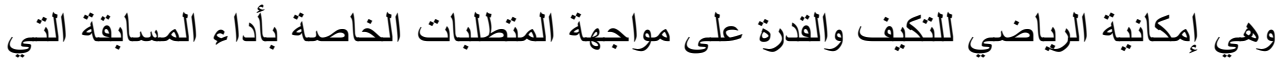

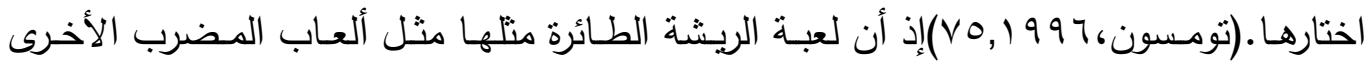

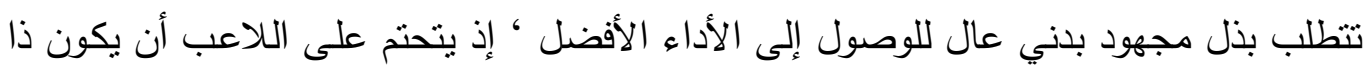
لياقة بدنبة عالية لمواجهة متطلبات اللعب والمنافسة، فاللياقة البذنية تساعد اللاعب على استثمار

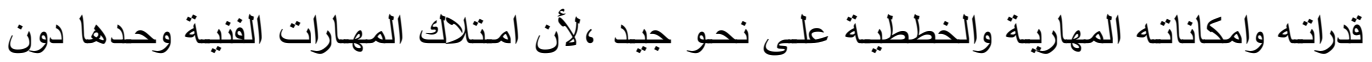

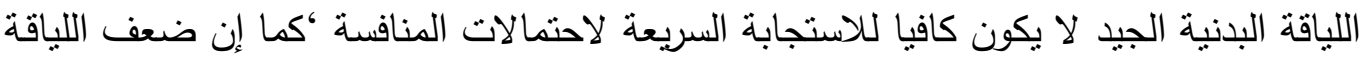

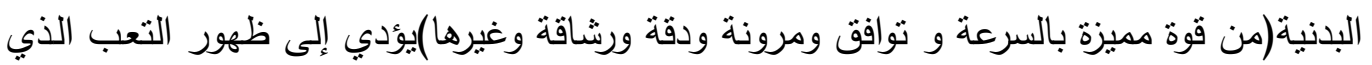

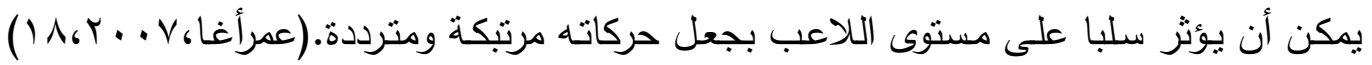

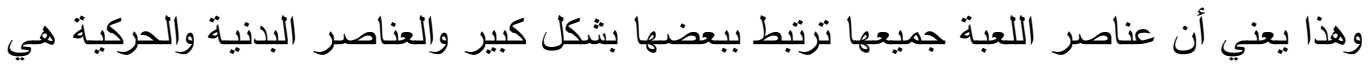
التي تقرر مستوى الأداء المهاري والخططي ، وهذا سبب الارتباط القوي والعلاقة الوثيقة بين

هذه العناصر (Bo omosc Gaard,1996 , 9-10)

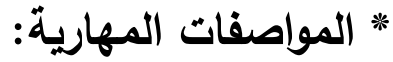

يؤدي الإعداد المهاري دورا مهما في تحقيق الإنجاز لمختلف الألعاب والأنشطة الرياضية ،كما أن هناك علاقة ارتباط قوية بين عناصر الإعداد الرياضي جميعها التي تشمل الإعداد الإدار

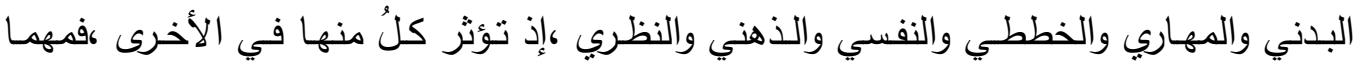
يصل مستوى الصفات البدنية للرياضي فإنه لن بسنطيع تحقيق النتائج المطلوبة ،مالم يرتبط ذلك

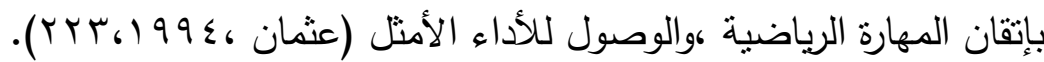
ولعبـة الريشة الطائرة واحدة مـن الألعاب الرياضية الميـزة بعدد كبير مـن المهارات الرئيسة والثانوية الدفاعية منها والهجومية ،وتقدم مستوى اللاعبين بها يعتمد وبدرجة كبيرة على مدى الإلى

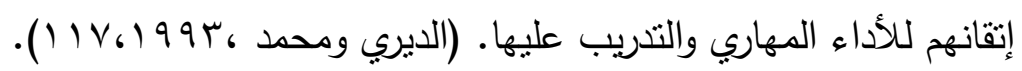

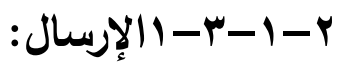

الإرسـال هو الرميـة التي يبدأ بها اللعب سـواء في أول المباراة أو في أعقاب تسجيل

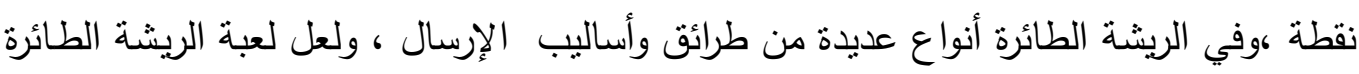
هي إحدى الألعاب التي يمكن فيها إحراز نقاط من ضربة الإرسال في حد ذاتها ، ويؤكد خبراء

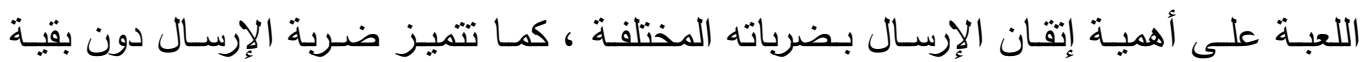

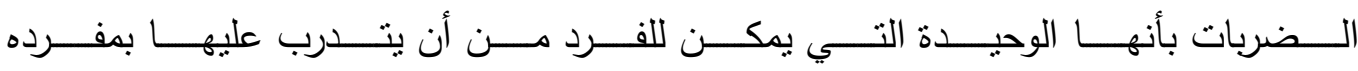

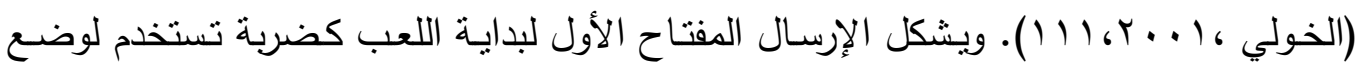
الريشة في اللعب في بداية كل تبادل للضربات ،بحيث ترسل الريشة إلى المكان الذي من الإسن 


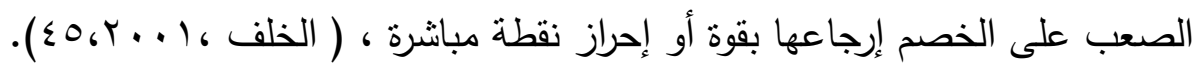

$$
\begin{aligned}
& \text { وهناك نوعان للإرسال : }
\end{aligned}
$$

-الإرسال العالي (الطويل):

وينفذ في الغالب بالوجه الأمامي للمضرب ،ويستخدم بشكل كبير في اللعب الفردي بحيث

ترسل الريشة لنطير إلى أعلى وأعمق مسنوى ممكن للحدود الخلفية لملعب الخصم لإجبار المنافس على الرجوع للوراء وإضعاف هجومـه ، إذ يتخذ المرسل وضعية الإرسال بوقوفه على العى بعد ثلاثة أقدام من خط الإرسال الأمامي وقريبا من خط الوسط ويضرب الريشة لتطير بمسار عال وبقدر كاف يمكن للريشة من الهبوط ببطء فوق ملعب المستقبل وإتاحة المجال للمرسل

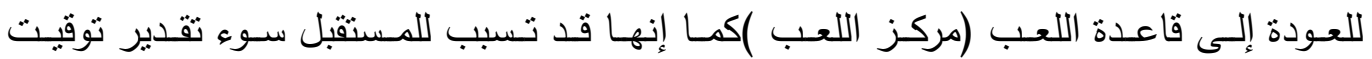

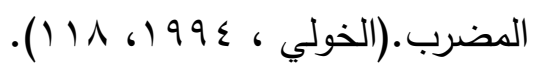
- الإرسال الواطئ (القصير):

ويكون إما بوجه المضرب الأمامي أو الخلفي منه وهو الأساس والأكثر استعمالا والفضل

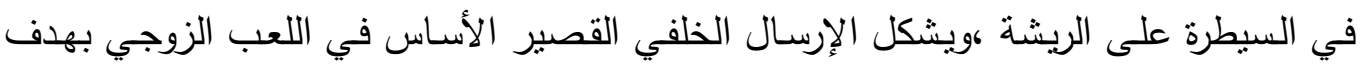

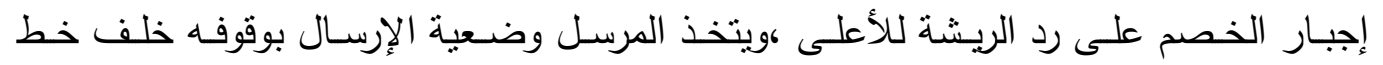

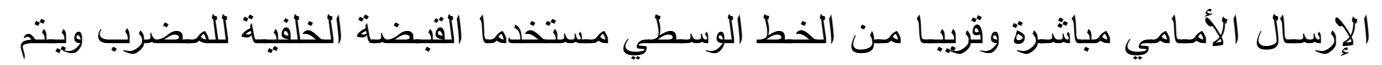
التركيز على حافة الثبكة العليا ،حتى يكون الإرسال أوطأ في الارتفاع قدر الامكان ،ولتسقط

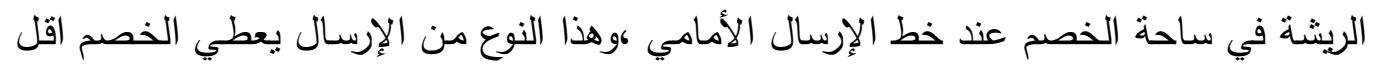
من · r\%من الوقت للتحرك والهجوم (24, 1995. Peter Roper).

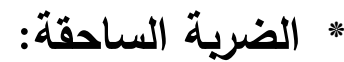

ويقصد بها توجيه الريشة بضربها بقوة بشكل حاد نحو الأسفل ،وهي المهارة الهجومية

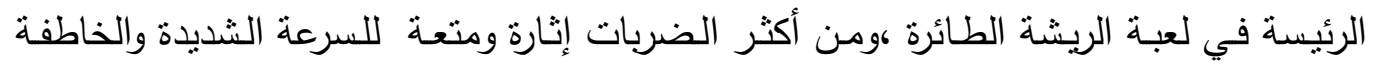

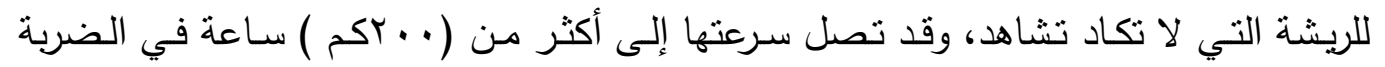

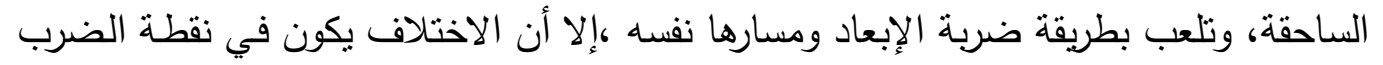

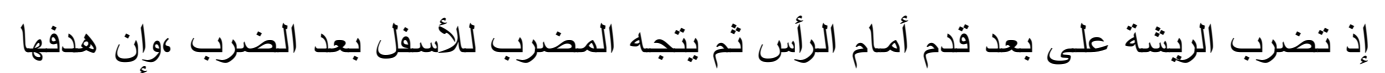

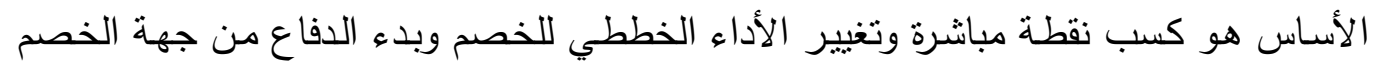




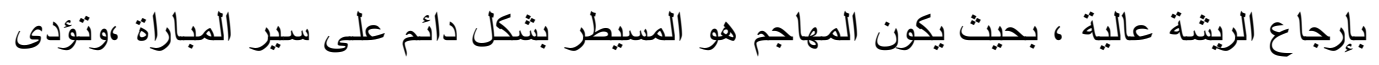
إما بالارتقاء وإما الوثب للأعلى وإما من الثبات (الخلف، (... r ، 10).

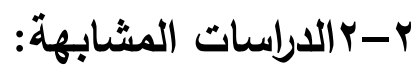

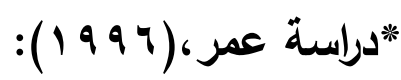

"تأثير التوقف عن التثريب على بعض عناصر اللياقة البننية الخاصة بلاعبي الكرة الطائرة"

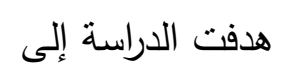

- الكثف عن اثر الثوقف عن التثريب لدةة (أسبوع واحد-أسبوعين)على بعض عناصر اللياقة البنية الخاصة بلاعبي الكرة الطائرة .

-الكثف عن النسب المئوية للهيوط في مستوى عناصر اللياقة البندية.

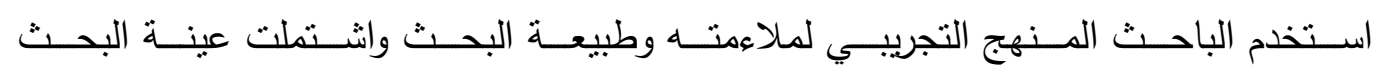

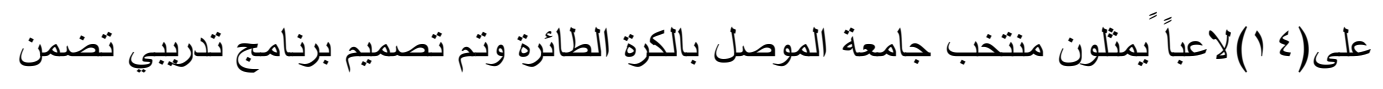

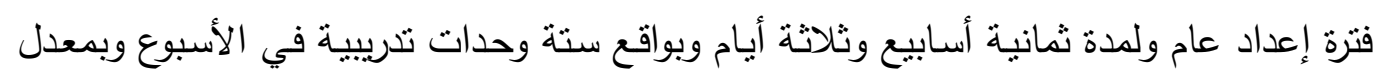

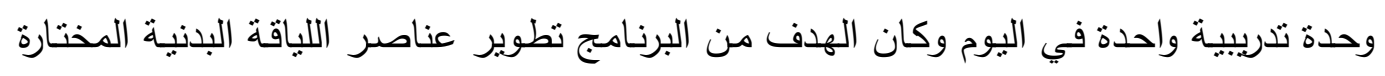

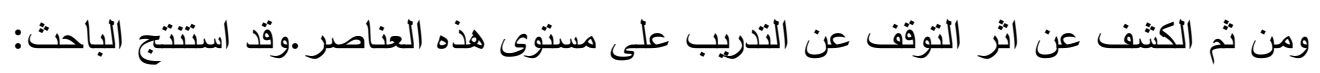

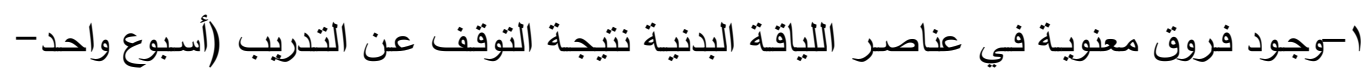

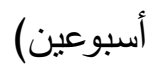

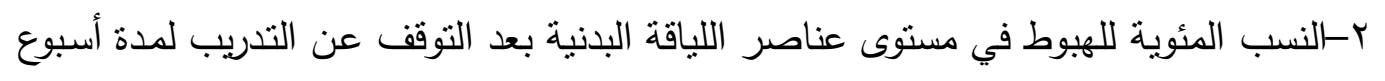

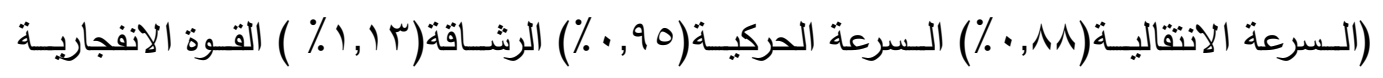

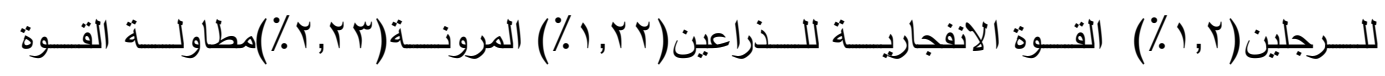

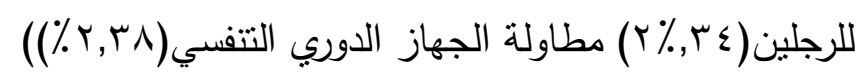

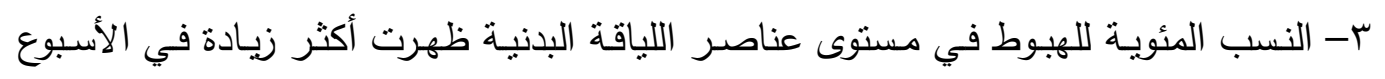

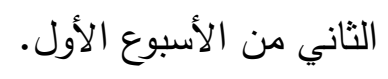

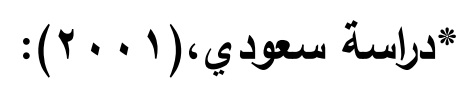
"أثر التوقف عن التريب في بعض عناصر الثلياقة البانية والأداء المهاري على جهازي الحلق والمقابض"

هدفت الدراسة إلى:

-الكثف عن النوقف عن التنريب لددة (أسبوع واحد-أسبوعين)على بعض عناصر اللياقة البننية 
لاى لاعبي الجمناستك على جهازي الحلق والمقابض.

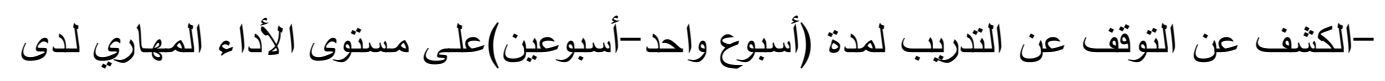
لاعبي الجمناستك على جهازي الحلق وحصان المقابض.

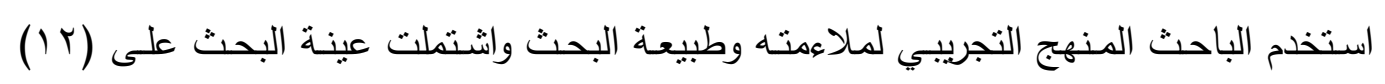

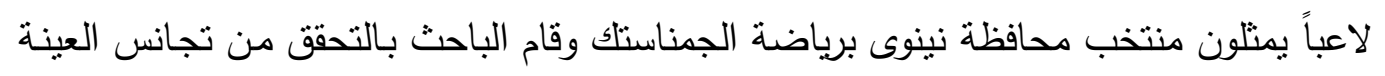

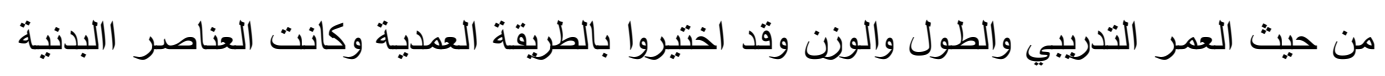
المختارة من قبل الخبراء (مطاولة القوة ،والقوة المميزة بالسرعة)وتم استتناج ما يأتي: 1- أحدث التوقف عن التدريب لمدة (أسبوع -أسبوعين)هبوط في مستوى عناصـر اللياقـة البدنية(مطاولة القوة،القوة المميزة بالسرعة).

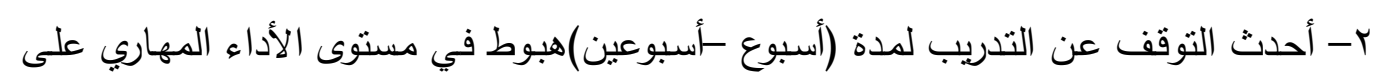
جهازي الحلق وحصان المقابض.

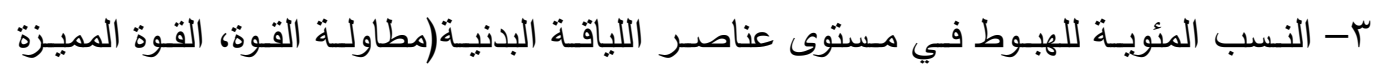
بالسرعة)كانت أكثر في الأسبوع الثاني منة في الأسبوع الأول.

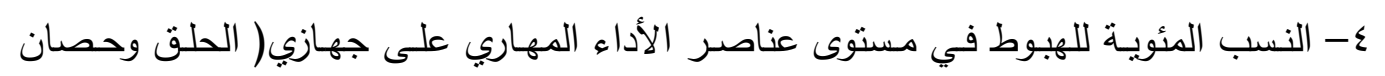
المقابض) كانت أكثر في الأسبوع الثاني منة في الأسبوع الأول. ه-كانت نسبة هبوط القوة المميزة بالسرعة أسرع من مطاولة القوة.

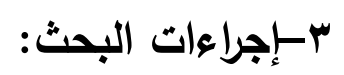

r- امنهج البحث:تم استخدام المنهج التجريبي لملاءمته وطبيعة البحث. r-r مجتمع البحث وعينته:اشتمل مجتمع البحث على (^)لاعبين يمنلون منتخب محافظة نينوى/لفئة المتقدمين ونم استبعاد لاعبين لعدم استمرارهم في الاختبارات البدنية والمهارية فأصبح

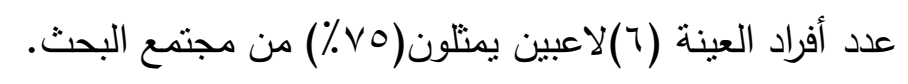

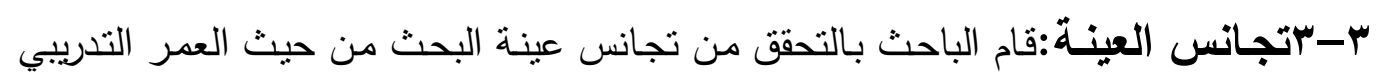
والوزن والطول والجدول (1) يبين المعاليم الإحصائية لهذه المتغيرات.

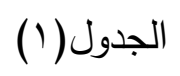

المعاليم الإحصائية لمتغيرات العمر والوزن والطول والعمر التدريبي لعينة البحث

\begin{tabular}{|l|l|l|l|}
\hline المتنغيرات & المعاليم الإحصائية \\
\hline
\end{tabular}




\begin{tabular}{|c|c|c|c|}
\hline r,q & 7,9 & 187 & الطول سم \\
\hline $1, \varepsilon Y$ & 9,7 & $T V, O$ & الوزن(كغم) \\
\hline$\vee, \wedge 9$ & 1,0 & 19 & العمرالزمني (سنة) \\
\hline$\Lambda, 7$ & 织 & 0 & العمر التدريبي (سنة) \\
\hline
\end{tabular}

من الجدول( (1)يتبين أن معامل الاختلاف لمتغيرات العمر والوزن والطول والعمر التدريبي لعينة البحث كان اقل من ( ٪ وهذا يدل على تجانس العينة، إذ يشيران

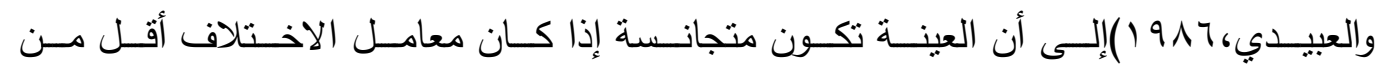

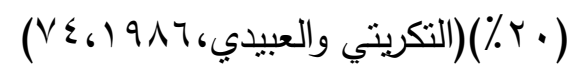

ب- \$وسائل جمع البيانات: تم استخدام الاستبيان والاختبارات والمقاييس لجمع البيانات

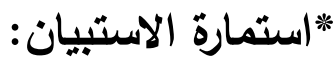

\section{أ-استمارة استبيان لغرض تحديد عناصر اللياقة البدنية الخاصة}

\section{والاختبارات الملاعمة لها:}

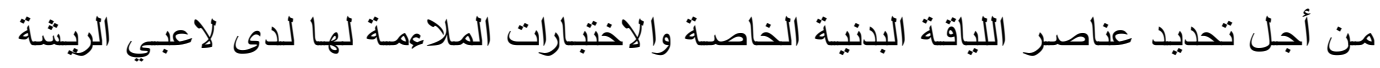

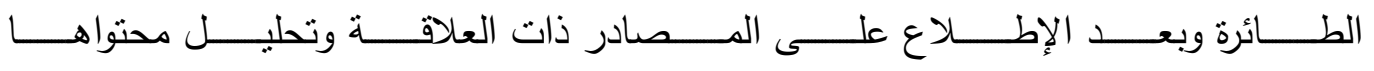

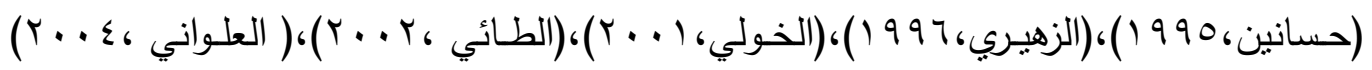

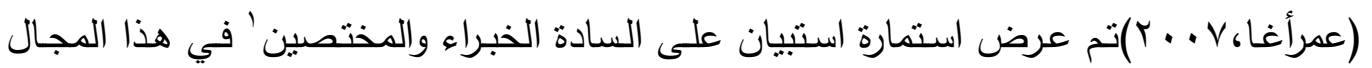

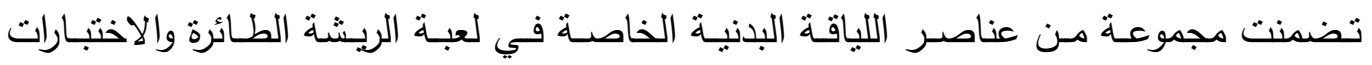
الملاءمة لها وكما موضح في ملحق رقم (1).وبعد تحديد أهم العناصر المختارة من فبل السادة

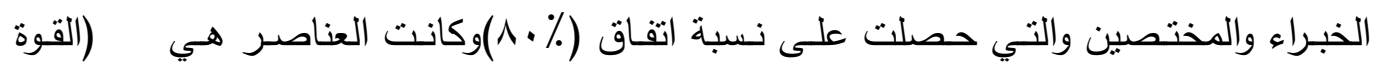
المميزة بالسرعة للذراعين والقوة المميزة بالسرعة للرجلين والمرونـة والرشاقة) و كذلك نم الاتفاق

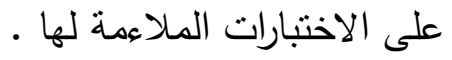
ب-استمارة استبيان لغرض تحديد أهم المهارات الأساسية والاختبارات

كلية التربية الرياضية /جامعة الموصل

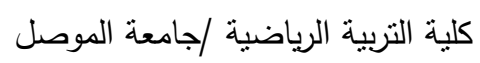
كلية التربية الرياضية /جامعة الموصل لريله كلية التربية الرياضية /جامعة الموصل

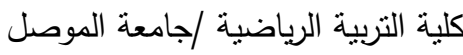

علم تدريب الرياضي قياس وتقويم علم تدريب الرياضي ولئمي قياس وتقويم علم تدريب الرياضي
1- أ.د إياد محمد عبد الله

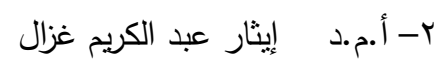
r- أ.م.د زياد يونس الصفار

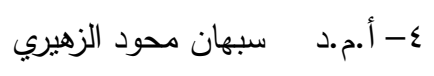
0- م.د نبيل محمد عبد الله 


\section{الملاعمة لها:}

من اجل تحديد المهارات الأساسية والاختبارات الملاءمة لها لاى لاعبي الريشة الطائرة وبعد

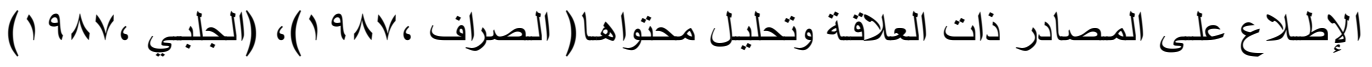

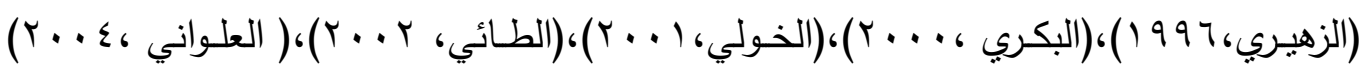

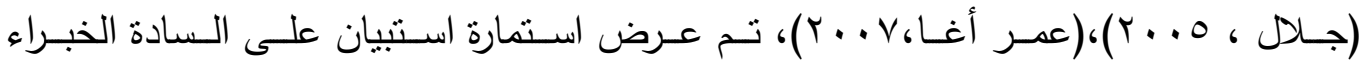

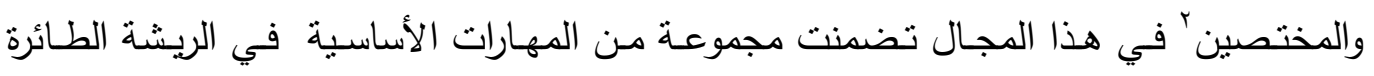
والاختبارات الملاعمة لها وكما هو موضح في ملحق رقم (؟).وبعد تحديد أهم العناصر المختارة

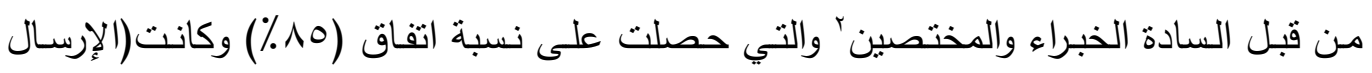

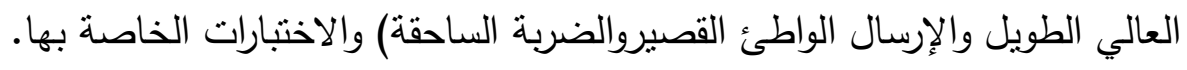
*الاختبارات:على الرغم من توفر معاملات الصدق والثبات والموضوعية للاختبارات البدنية

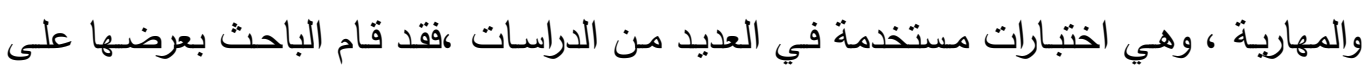

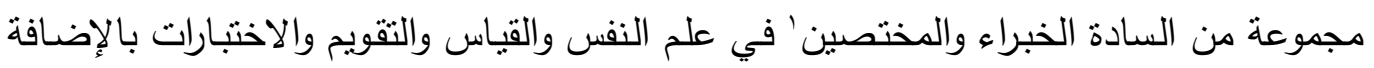
إلى تخصص بعضهم في ألعاب المضرب وأكدوا جميعهم صلاحيتها وملاءمتها للنطبيق على عينة البحث.وكانت الاختبارات البدنية كالأتي: أ- الاختبارات البدنية: - البنة

\section{اولاً: اختبار الركض المرتد 9 متر × بامرات} - الهدف من الاختبار :قياس الرشاقة. - الأدوات المطلوبة: ملعب كرة طائرة قانوني بدون شبكة،أو رسم خطين متوازيين تكون المسافة

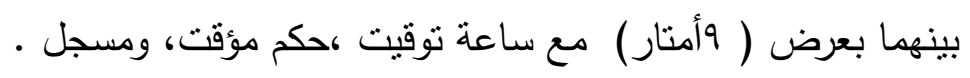
- إجراء الاختبار : يقف المختبر خلف خط البداية للملعب وعند سماع ومشاهدة الإشارة يقوم

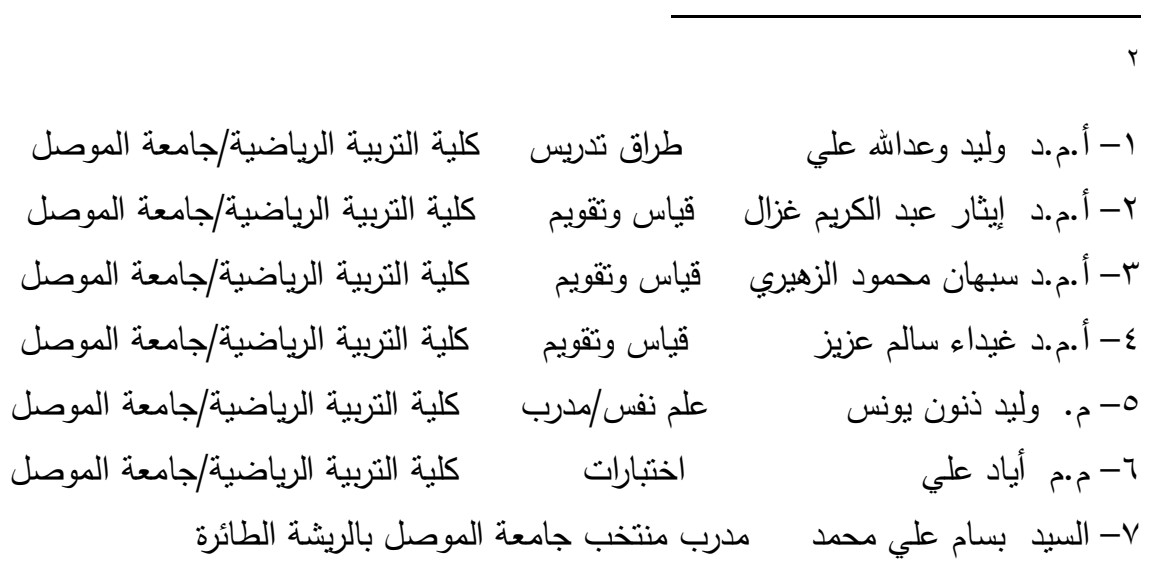


المختبر بالجري بأقصى سرعة إلى الجهة الثانية ثم يعود إلى نقطة البداية ثم يعود إلى الجهة الثانية وهكذا ( امرات).

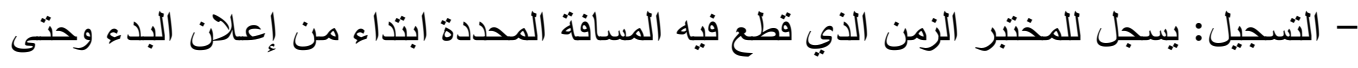

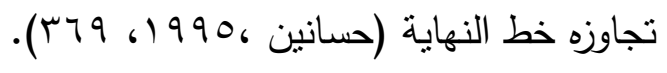

ثانياً:اختبار ثني الذراعين ومدهما على جهاز المتوازي الواطئ خلال ( ـ 1 ثا). الهذف من الاختبار :قياس القوة المميزة بالسرعة للذراعين. - الأدوات المطلوبة:جهاز متوازي واطئ ، ساعة نوقيت. -إجراء الاختبار : من وضع الاستتاد الأمامي باليدين على جهاز المتوازي ( الواطيء ) وعند

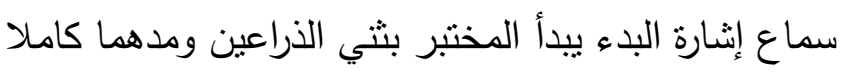
- التسجيل: تسجل عدد المرات الثني والمد للذراعين خلال (• (ثا). - هناك بعض الشروط عند نطبيق الاختبار : 1-استقامة جسم اللاعب وعدم التوقف عند أداء الاختبار.

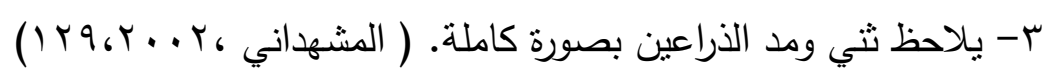
ثالثاً: اختبار الوثب للأمام لأقصى مسافة خلال (ه ثواني) .

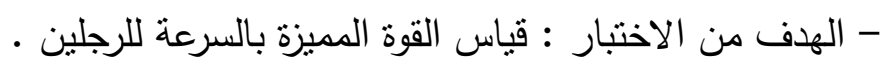
- الأدوات المطلوبة : أرض ملعب في حدود (•r-0 هبمتر ) ، شريط قياس ، ساعة توقيت - إجراء الاختبار : مـن وضـع ثتي الركبتين كاملا، وعند سـماع إثـارة البدـ يقوم المختبر

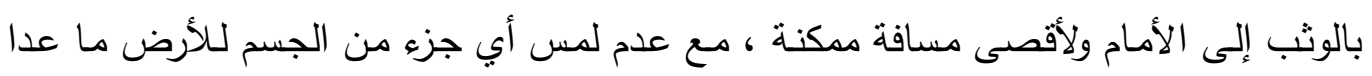
القدمين وعدم الخروج عن الخطوط المرسومة.

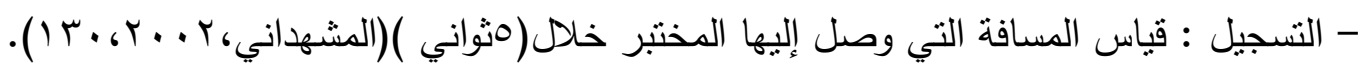
رابعاً: اختبار ثني الجذع إلى الأمام والأسفل من الوقوف على الصندوق .

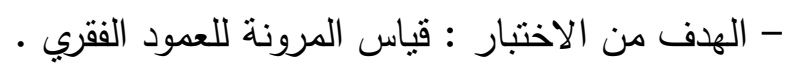

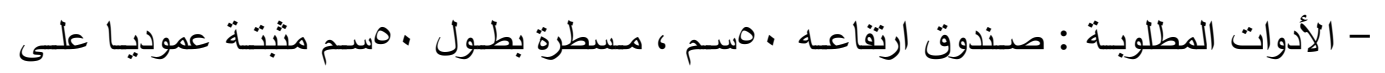

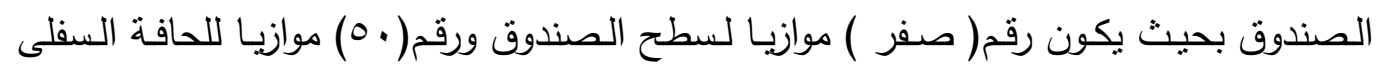




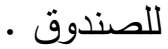

- إجراءات الاختبار : يقف المختبر فوق الصندوق والقدمان مضمومتان مع تثبيت القدمين على حافـة الصندوق مـع الاحتفاظ بـالركبتين ممدودتين ، ثم يقوم المختبر بثتي جذعـه إلى الأمـام والأسفل محاولا تمرير أصـابع اليد في مستوى اقل من سطح الصندوق والثبات في هذا الوضع لحساب القراءة بالسنتمنز السالب أو الموجب وذللك عن مستوى سطح الصندوق •

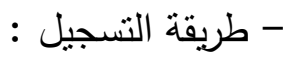

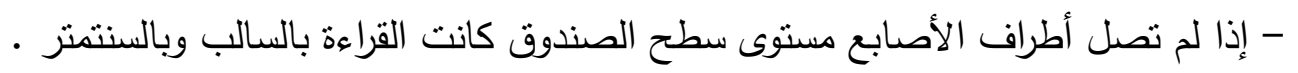
- إذا تخطت أطراف الأصسابع مستوى سطح الصندوق كانت القراءة بالموجب وبالسنتمتر .

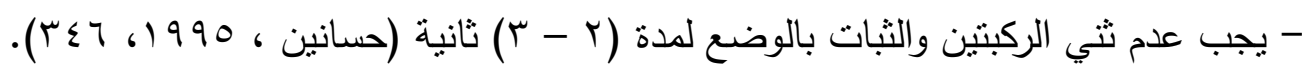
ب- الاختبارات المهاريةة: أولاً: اختبار الإرسال القصير الواطيء. - هدف الاختبار : قياس الدقة لمهارة الإرسال القصير •

- الأدوات المطلوبة: مضارب ريشة ، كرات ريشة الطائرة ، حبل مطاطي ، ملعب مخطط بتصميم الاختبار ،كما في الشكل رقم ( (1)في ملحق رقم (r).

- يبلـغ قياس كل منطقة كمـا يـأتي : منطقة ( مدرجات ) نصف قطر (0,^) سـ مسن المركز

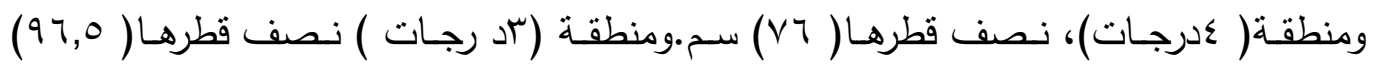
سم ).ومنطقة (rدرجة )نصف قطرها (I IV) سم. ومنطقة( (درجة ) باقي منطقة الإرسال • - طريقة تقفيذ الاختبـار : يقف المرسـل في مكان الإرسـال (× ) ويرسـل (•rمحاولـة) على مجموعتين بحيث تمر الريشة من بين الشبكة والحبل الذي يرتفع عنها (إسم ) محاولا إسقاط الريشة على المنطقة ذات الدرجة الأعلى.

- حساب النقاط : تعطى الدرجة على وفق مكان سقوط الريشة ، الريشة التي تقع على خط بين منطقتين تعطى الدرجة الأعلى ، الإرسال الذي لا يمر من بين الحبل والثبكة ولا يسقط على إحدى المناطق يعطى صفرا ، الإرسال الذي يصطدم بالحبل يعاد مرة أخرى،الدرجـة

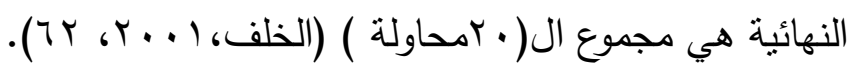

ثانياً: اختبار الإرسال العالي الطويل . - هدف الاختبار : قياس دقة مهارة الإرسال العالي الطويل . - الأدوات المطلوبة: مضارب ريشة ، كرات ريشة الطائرة ،ملعب مخطط بتصميم الاختبار كما 


$$
\text { في الثكل رقم (r)في الملحق رقم (r). }
$$

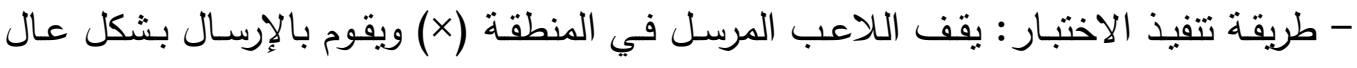
وطويل بحيث تعبر الريشة من فوق الثبكة ومن ثم من فوق اللاعب الذي يحمل مضربه ويده

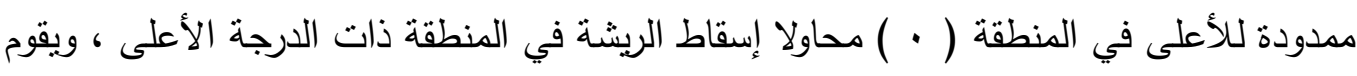

$$
\text { بإرسال ( ب أ) محاولة. }
$$

- حساب النقاط :

- تعطى الدرجة على وفق مكان سقوط الريشة .

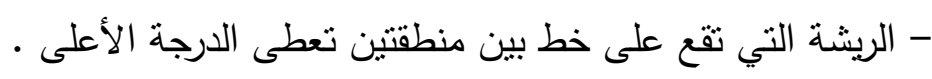

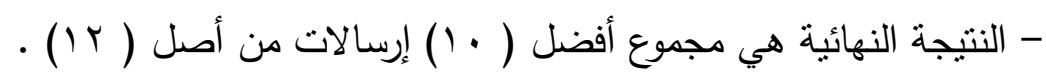

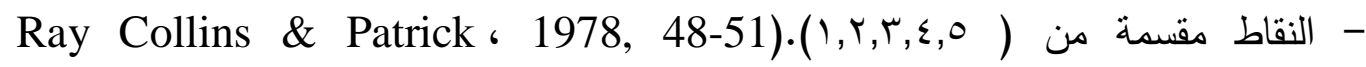

(Hadges

\section{ثالثاً: اختبار الضرية الساحقة.}

- هدف الاختبار : قياس الإنجاز لمهارة الضربة الساحقة .

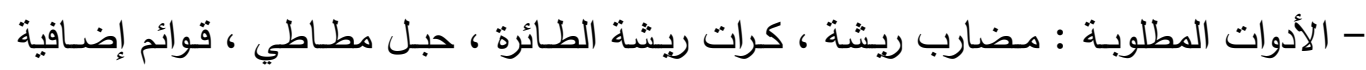

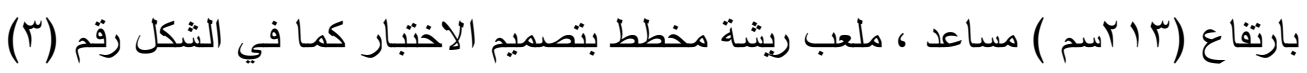

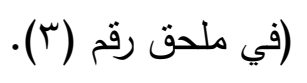

- طريقة تنفيذ الاختبار : يقف اللاعب في المكان المخصص له (×) ويقوم برد الريشة المرسلة

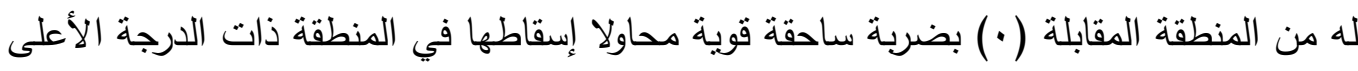
بشرط أن تمر الريشة من فوق الثبكة ومن تحت الحبل المثبت خلف الثبكة على بعد ( • آسم )

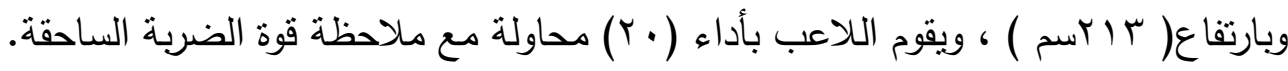

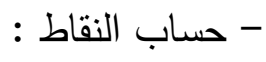

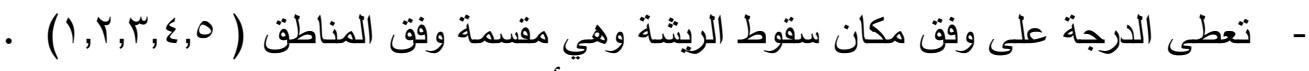

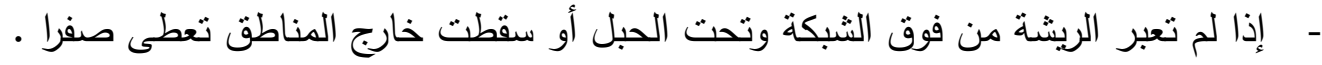

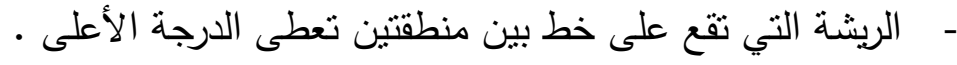

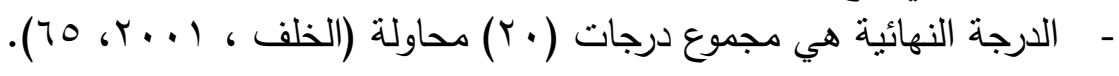

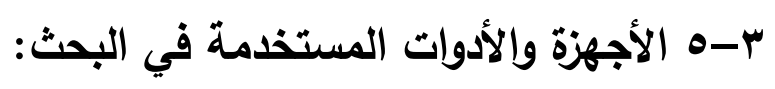

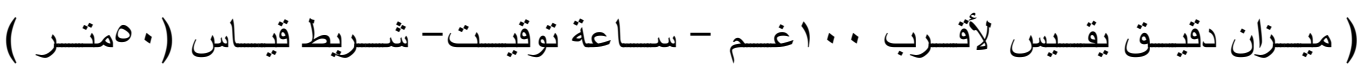
لاصق ورقي - أرقام توضيحية(لمناطق لعب الكرات في الاختبارات)- مضارب الريشة الطائرة

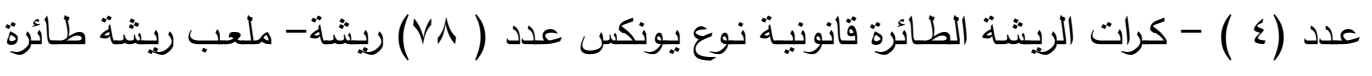


وملحقاته ( قوائم +شبكة ) عدد ا- قوائم إضافية مع أعمدة خشبية لازمة لعدد من الاختبارات المهارية).

\section{ب-هتطبيق التجربة الميدانية:}

"المنهاج التدريبي:اشتمل المنهاج التدريبي على ثلاثة دورات تدريية منوسطة تكونت كل دورة من ثلاثة أسابيع وبواقع ثلاث وحدات تدريبية أسبوعياً وتم تتفيذ المنهاج التدريبي للفترة

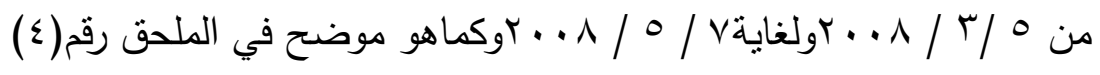

*التجرية الاستطلاعية:

تم تطبيق التجربة الاستطلاعية يوم الخميس الموافق / / . . . rعلى منتخب جامعة الموصل

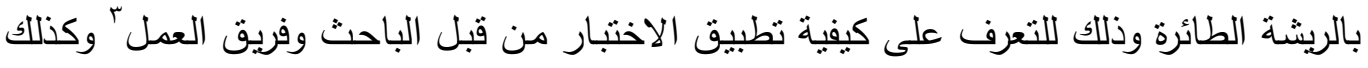
على الأخطاء المحتملة لتفاديها أثناء تطبيق الاختبارات. *تبارات تحديد المستوى وإختبارات التوقف للأسابيع الأربعة الأنطة

بهدف تحديد المؤشرات العلمية للآثار الناتجة عن النوقف عن التدريب على بعض عناصر

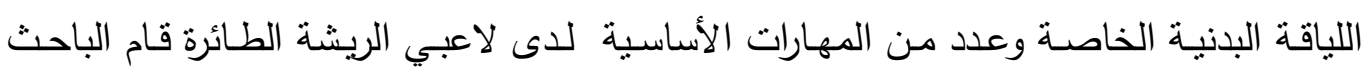
$60 / 11)$

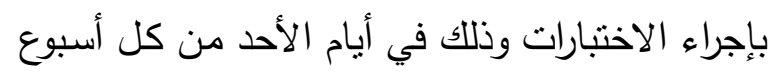

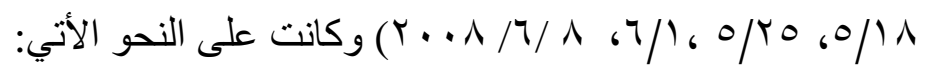

1- اختبارات تحديد المستوى :تم إجراء الاختبارات للاعبين بعد التوقف عن التدريب مباشرةً

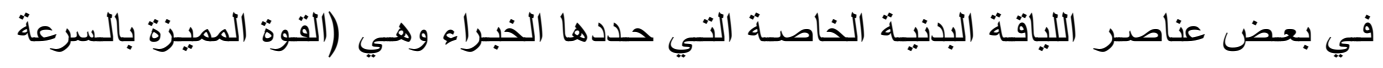

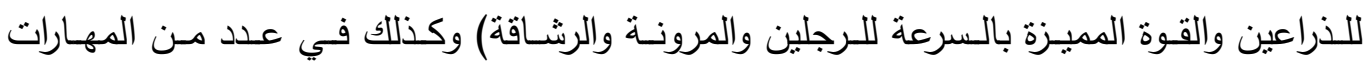

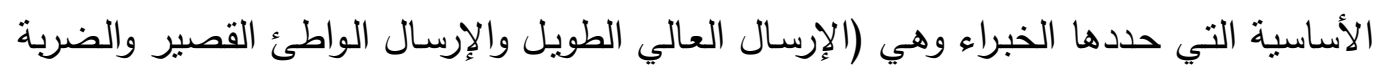
الساحقة) لدى لاعبي الريشة الطائرة. 


\section{r- ا بتبارات التوقف للأسابيع الأريعة:}

تم إجراء الاختبارات لعينة البحث بعد توقفهم الكامل عن التدريب (لددة أسبوع واحد وأسبوعين

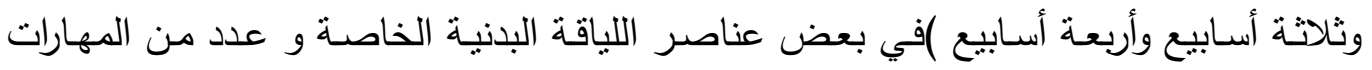
الأساسية في الريثة الطائرة.

وقد راعى الباحث إجراء الاختبارات في النوقف لمدة( أسبوع ،أسبوعين ،ثلاثة أسابيع ،أربعة

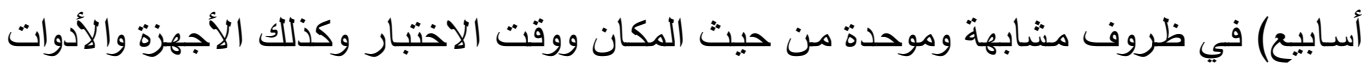

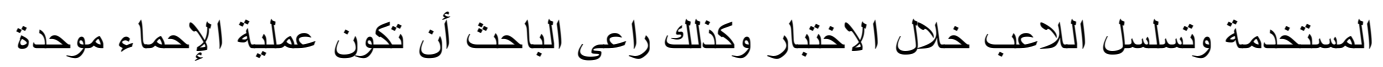
وتسلسل محتواها من التمارين وتقسيمها الزمني.

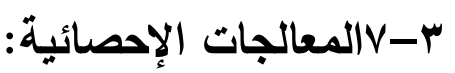

$$
\text { -الوسط الحسابي -الانحراف المعياري - --النسبة المئوية }
$$$$
\text { -معامل الاختلاف -اختبار (ت) (النكريني والعبيدي، 1999، ـ1-101) }
$$

؛-عرض وتحليل ومناقثة النتائج:

؛ - 2 - اعرض النتائج وتحليلها:

*عرض نتائج اختبار تحديد المستوى واختبارات التوقت عن التدريب للأسابيع الأربعة لعناصر اللياقة البلنية الخاصة وعدد من المهارات الأساسية

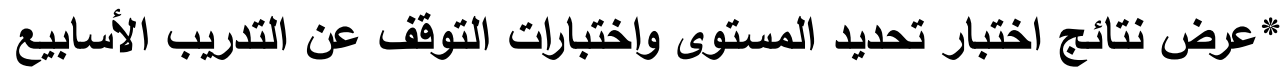
الأربعة لعناصر اللياقة البلنية

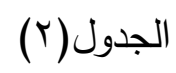


يبين المعاليم الإحصائية والمتغيرات لاختبارات تحديد المستوى والتوقف عن التدريب لعناصر اللياقة البدنية للأسابيع الأربعة

الجدول(r)يبين المعاليم الإحصائية والمتغيرات لعينة البحث في اختبار تحديد المستوى والاختبارات

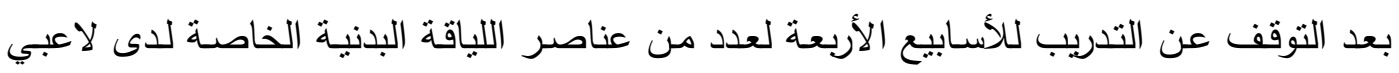

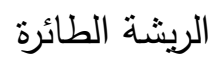

* عرض نتائج اختبار تحديد المستوى واختبارات التوقف عن التدريب الأسابيع لرع الأربعة للمهارات الأساسية المبتوف والتبات

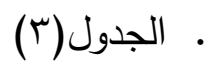

يبين المعاليم الإحصائية والمتغيرات لاختبارات تحديد المستوى والتوقف عن التدريب لعدد من

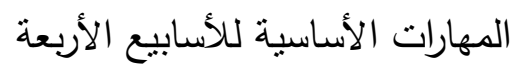

\begin{tabular}{|c|c|c|c|c|c|c|c|c|}
\hline \multicolumn{2}{|c|}{ المرونة } & \multicolumn{2}{|c|}{$\begin{array}{c}\text { القوة الميزة بالسرعة } \\
\text { للرجلين } \\
\text { (متر) }\end{array}$} & \multicolumn{2}{|c|}{ بالسرعة للذراعين المميزة } & \multicolumn{2}{|c|}{ الرثناقة } & الكعاليم الإحصائية \\
\hline$\varepsilon^{ \pm}$ & سَ & $\varepsilon^{ \pm}$ & سَ & $\varepsilon^{ \pm}$ & سَ & $\varepsilon^{ \pm}$ & سَ & \\
\hline $1, \leqslant 0$ & Ir & $\cdot, \leqslant r$ & 17,07 & $\cdot, \wedge 9$ & ir & $\cdot, \varepsilon$. & $M, V \wedge$ & تحديد المستوى \\
\hline$r, r v$ & $q, Y_{1}$ & $\cdot, \wedge 7$ & $10, \cdot \varepsilon$ & $\cdot, \wedge_{1}$ & سז, 1 & $\cdot, V \mu$ & $10, r$ & للأسبو اختبار التوقف الأول \\
\hline $1, \mathrm{VT}$ & $\Lambda, 7 \wedge$ & $\cdot, V r$ & $1 \leqslant, 70$ &., 01 & $9, \cdot 7$ & r & 10,1 & للأسبو اختبار التوقان \\
\hline $1, v \varepsilon$ & $v, 0$ &., $0 \leqslant$ & 1 & $\cdot, \varepsilon$. & $9, \cdot r$ & $\cdot, \leqslant V$ & $10, \leqslant 1$ & للأسبوع التثار التوقف \\
\hline 1,71 & $7, \vee \wedge$ & ד & IY,AT & $\cdot, \Lambda_{r}$ & $V, 77$ & $\cdot, \leqslant \wedge$ & $10, V 7$ & لأسبوع لرابع التوقف \\
\hline
\end{tabular}


الجدول(r)ييين المعاليم الإحصائية والمتغيرات لعينة البحث في اختبار تحديد المستوى والاختبارات

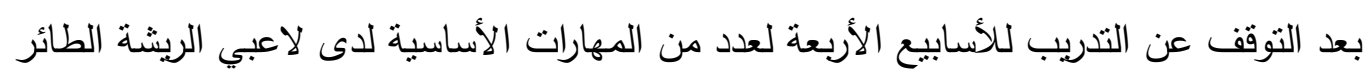

• عرض نتائج اختبارات تحديد المستوى والتوقف عن التدريب للأسابيع الأربعة للقوة المييزة بالسرعة للأراعين

\begin{tabular}{|c|c|c|c|c|c|c|}
\hline \multicolumn{2}{|c|}{ الكبس الساحق } & \multicolumn{2}{|c|}{ الإرسال العالي } & \multicolumn{2}{|c|}{ الإرسال الواطئ } & الكعاليم الإحصائية \\
\hline$\varepsilon^{ \pm}$ & س & $\varepsilon^{ \pm}$ & س س س س & $\varepsilon^{ \pm}$ & س س & \\
\hline$r, \cdot \varepsilon$ & Ar, 17 & $r, 19$ & $\Gamma \varepsilon$ & $r, \cdot q$ & (1) & تحديد المستوى \\
\hline$r, 07$ & VV,Ar & $r, 07$ & $r q, \wedge r$ & $r, q$ r & 70,74 & للأستبوع الأوقف \\
\hline$r, r)$ & VI, 17 & 1,14 & $r \wedge, T$ & $r, r$ & Tा T T & للأستبو ع التاني \\
\hline$r, 17$ & $V \varepsilon$ & $1, \leqslant V$ & $r \uparrow, \wedge$ & $r, Y \wedge$ & T), ז & للأسبوع الثالث \\
\hline$\varepsilon, \varepsilon V$ & v) & 1,97 & $r \leqslant, r$ & $r, 94$ & 09,17 & للأسبو ع لر ابع \\
\hline
\end{tabular}

جدول(乏)

يبين متغيرات البحث والمعاليم الإحصائية لاختبارات تحديد المستوى والتوقف عن التدريب

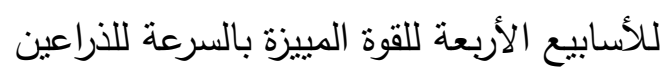




\begin{tabular}{|c|c|c|c|c|c|}
\hline اللهبة المئوية & قالمحسوبة & الفرق بين & $\varepsilon \pm$ & س & أكعالم الإحصائية \\
\hline \multirow{2}{*}{$\% \backslash r, q \backslash$} & \multirow{2}{*}{ *0 } & \multirow{2}{*}{$1,7 \mathrm{~V}$} & $\cdot, \wedge 9$ & ir & تحديد المستوى \\
\hline & & & $\cdot, \wedge)$ & ט & الأسبوع الأول \\
\hline \multirow{2}{*}{$\% r \leq, 0$} & \multirow{2}{*}{$\because V$} & \multirow{2}{*}{$r, q \leq$} & $\cdot, \wedge 9$ & ir & تحديد المستوى \\
\hline & & &., 01 & $9, .7$ & الأسبوع الثاني \\
\hline \multirow{2}{*}{$\% \curlyvee \varepsilon, \wedge r$} & \multirow{2}{*}{$* \wedge, Y_{1}$} & \multirow{2}{*}{$r, 91$} & $\cdot, \wedge 9$ & Ir & تحديد المستوى \\
\hline & & & $\cdot, \varepsilon$. & $q, \cdot r$ & الأسبوع الثالث \\
\hline \multirow{2}{*}{$\%$ \%ч, I } & \multirow{2}{*}{$* 1 \cdot, r V$} & \multirow{2}{*}{$\varepsilon, \Gamma \varepsilon$} & $\cdot, \wedge 9$ & Ir & تحديد المستوى \\
\hline & & & •, Ar & $V, 74$ & الأسبوع الرابع \\
\hline
\end{tabular}

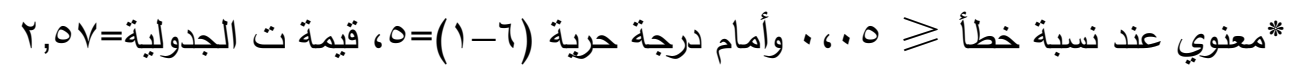

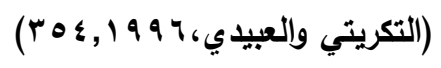

يتبين من الجدول (ع) وجود فروق ذات دلالـة معنويـة بين اختبار تحديد المستوى واختبارات

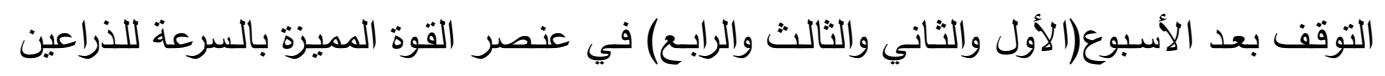

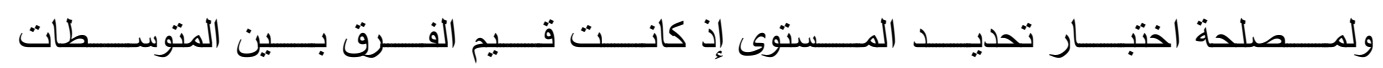
(

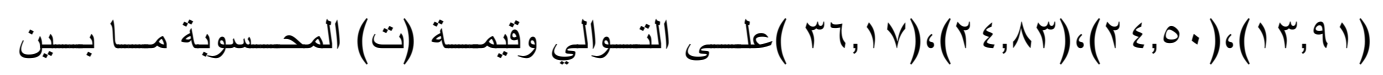

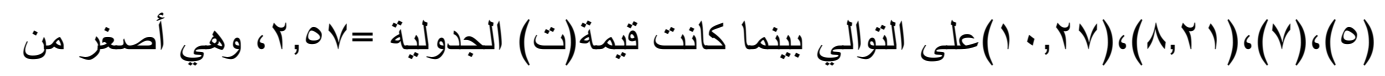

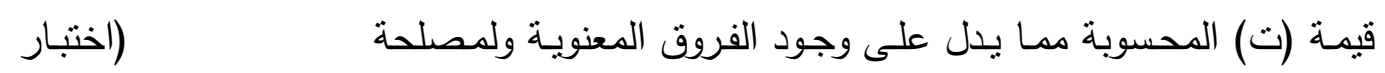
تحديد المستوى).

عرض نتائج اختبارات تحديد المستوى والتوقف عن التدريب للأسابيع الأريعة للقوة المييزة بالسرعة للرجلين

جدول(0) 
يبين متغيرات البحث والمعاليم الإحصائية لاختبارات تحديد المستوى والتوقف عن التدريب للأسابيع الأربعة للقوة المييزة بالسرعة للرجلين لإنالين

\begin{tabular}{|c|c|c|c|c|c|}
\hline للالنسبة المئوية & قالمسمة ت & الفرق بين & $\varepsilon^{ \pm}$ & س & الكعالم الإحصائية \\
\hline \multirow{2}{*}{$\% 9.1 \vee$} & \multirow{2}{*}{ * } & \multirow{2}{*}{$1.0 r$} & $\cdot, \leqslant r$ & 17,07 & تحديد المستوى \\
\hline & & & $\cdot, \wedge 7$ & $10, \cdot \varepsilon$ & الأسبوع الأول \\
\hline \multirow{2}{*}{$\% 11$, or } & \multirow{2}{*}{$* \wedge, 0 \leqslant$} & \multirow{2}{*}{1,91} & $\cdot, \varepsilon r$ & 17,07 & تحديد المستوى \\
\hline & & & $\cdot, \mathrm{V} r$ & $1 \leq, 70$ & الأسبوع الثاني \\
\hline \multirow{2}{*}{$\% 1 r, 17$} & \multirow{2}{*}{$* 11,0 \mathrm{~V}$} & \multirow{2}{*}{ r.11 } & $\cdot, \varepsilon r$ & 17,07 & تحديد المستوى \\
\hline & & &., $0 \leqslant$ & $1 \leqslant, r \wedge$ & الأسبوع الثالث \\
\hline \multirow{2}{*}{ \%rr.rs } & \multirow{2}{*}{$* 10, \cdot r$} & \multirow{2}{*}{$r, v$} & •, $\leqslant r$ & 17,07 & تحديد المستوى \\
\hline & & & $\cdot, 77$ & $M, \wedge T$ & الأسبوع الرابع \\
\hline
\end{tabular}

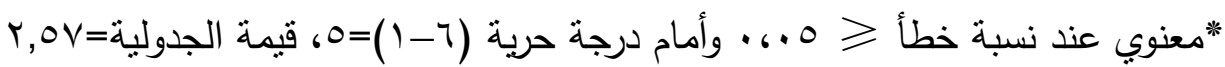
يتبين من الجدول (0) وجود فروق ذات دلالمة معنوية بين اختبار تحديد المستوى واختبارات

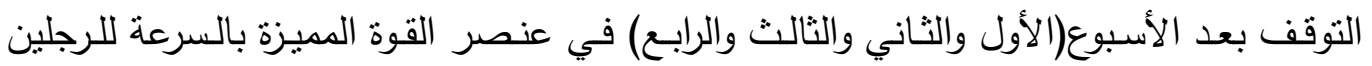

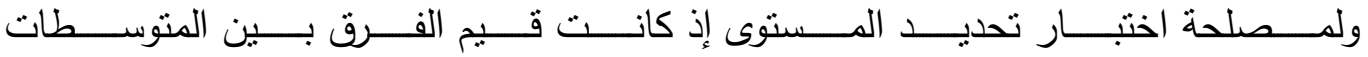

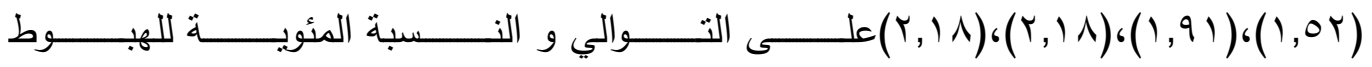

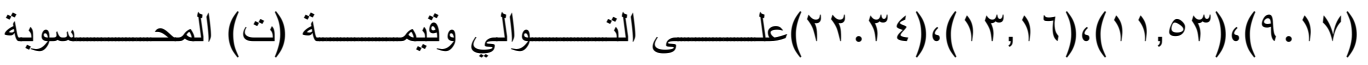

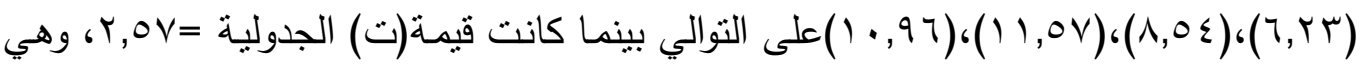
أصغر من قيمة (ت) المحسوبة مما يدل على وجود الفروق المعنوية ولمصلحة اختبار

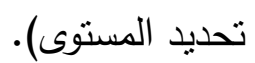

• عرض نتائج اختبارات تحديد المستوى والتوقف عن التتريب 


\section{لكلأسابيع الأربعة للمرونة}

جدول(T)

يبين متغيرات البحث والمعاليج الإحصائية لاختبارات تحديد الستنوى والتوقق عن التنريب

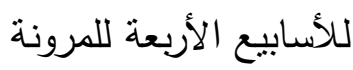

\begin{tabular}{|c|c|c|c|c|c|}
\hline للالنبة المئوية & قالمسمة ت & الفرقين & $\varepsilon^{ \pm}$ & س & الكعالم الإحصائية \\
\hline \multirow{2}{*}{$\%$ rr, ro } & \multirow{2}{*}{$* \varepsilon, 1$} & \multirow{2}{*}{ r,V } & $1, \leqslant 0$ & ir & تحديد المسنوى \\
\hline & & & $r, r V$ & $9, Y)$ & الأسبوع الأول \\
\hline \multirow{2}{*}{$\% \curlyvee \curlyvee, T \uparrow$} & \multirow{2}{*}{$* 4, r_{0}$} & \multirow{2}{*}{ r r } & $1, \leqslant 0$ & ir & تحديد المستوى \\
\hline & & & $1, \mathrm{~V} r$ & $\lambda, \pi$ & الأسبوع الثاني \\
\hline \multirow{2}{*}{$\% r v, 0$} & \multirow{2}{*}{$* \vee, \vee 1$} & \multirow{2}{*}{$\varepsilon, 0$} & $1, \leqslant 0$ & ir & تحديد المستوى \\
\hline & & & $1, Y \varepsilon$ & $v, 0$ & الأسبوع الثالث \\
\hline \multirow{2}{*}{$\% \leqslant r, 0$} & \multirow{2}{*}{$* 9,07$} & \multirow{2}{*}{$0, r Y$} & $1, \leqslant 0$ & ir & تحديد المستوى \\
\hline & & & 1,71 & $7, \mathrm{YA}$ & الأسبوع الرابع \\
\hline
\end{tabular}

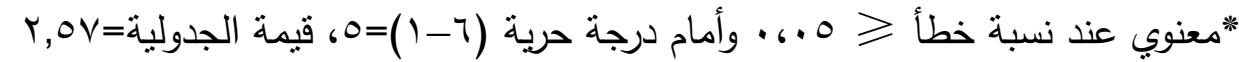

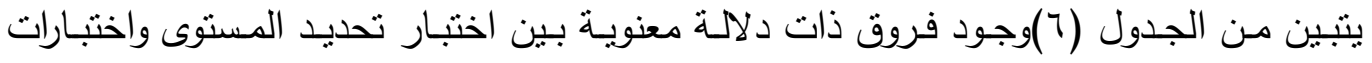

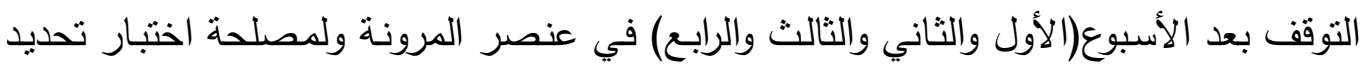

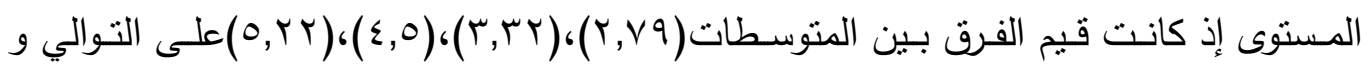

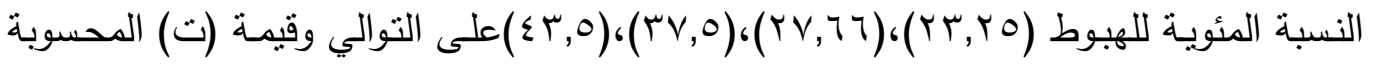

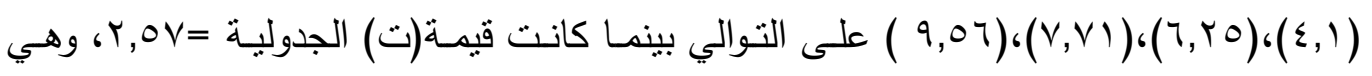

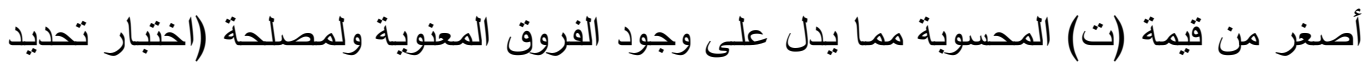
(المستوى).

*عرض نتائج اختبارات تحديد المستوى والتوقف عن التدريب للأسابيع الأربعة ) 


\section{للاشنة}

جدول(v)

يبين متغيرات البحث والمعاليم الإحصائية لاختبارات تحديد المستوى والتوقف عن التدريب للأسابيع الأربعة للرشاقة

\begin{tabular}{|c|c|c|c|c|c|}
\hline اللسبة المئوية & قالمحسوبة & الفرق بين & $\varepsilon^{ \pm}$ & سَ & الكولالم الإحصائية \\
\hline \multirow{2}{*}{$\% q, \cdot \vee$} & \multirow{2}{*}{ * r,o } & \multirow{2}{*}{$1, Y_{0}$} & $\cdot, \varepsilon$ & $1 r, v \wedge$ & تحديد المستوى \\
\hline & & & $\cdot, \mathrm{VT}$ & $10, r$ & الأسبوع الأول \\
\hline \multirow{2}{*}{$\% q, \vee q$} & \multirow{2}{*}{$* 9,70$} & \multirow{2}{*}{1, ro } & $\cdot, \varepsilon$ & $\mid r, V A$ & تحديد المستوى \\
\hline & & & 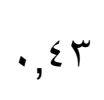 & 10,11 & الأسبوع الثناني \\
\hline \multirow{2}{*}{ \% \%,r, } & \multirow{2}{*}{$* q, 9}$. & \multirow{2}{*}{ I,V } & $\cdot, \leqslant$ & $M, \nabla \wedge$ & تحديد المستوى \\
\hline & & & $\cdot, \varepsilon V$ & $10, \leqslant 1$ & الأسبوع الثالث \\
\hline \multirow{2}{*}{$\%) \leqslant, r$} & \multirow{2}{*}{$* \wedge, 97$} & \multirow{2}{*}{1,91} & $\cdot, \varepsilon$ & $I T, Y \wedge$ & تحديد المستوى \\
\hline & & & $\cdot, \leqslant \wedge$ & 10,17 & الأسبوع الرابع \\
\hline
\end{tabular}

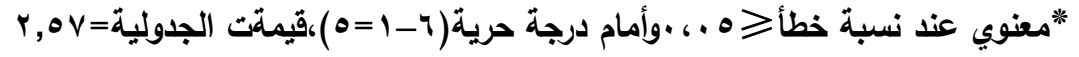

يتبين من الجدول (V)وجود فروق ذات دلالـة معنويـة بين اختبار تحديد المستوى واختبارات

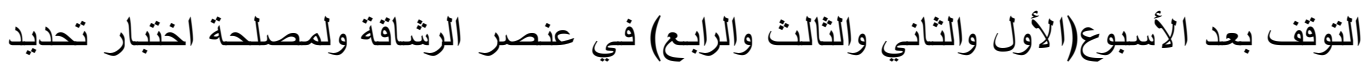

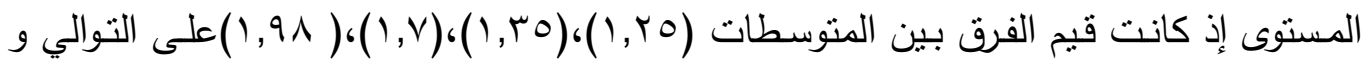

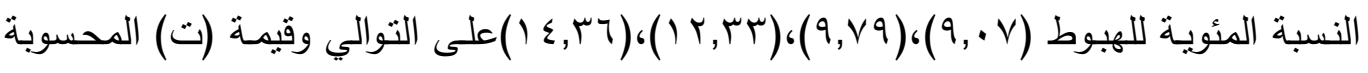

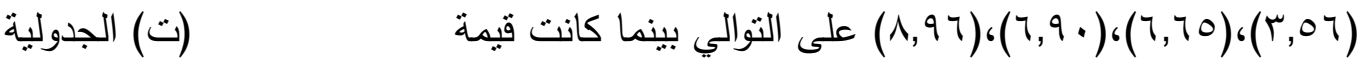

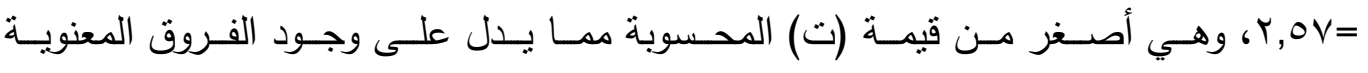

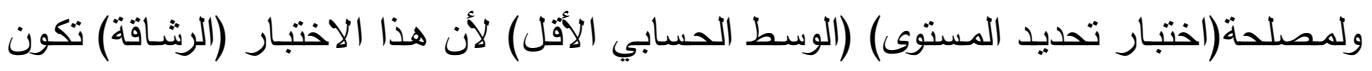

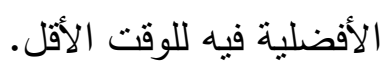


* عرض نتائج اختبار تحديد المستوى واختبارات التوقف عن التدريب للأسابيع التوبية الأربعة لعدد من المهارات الأساسية

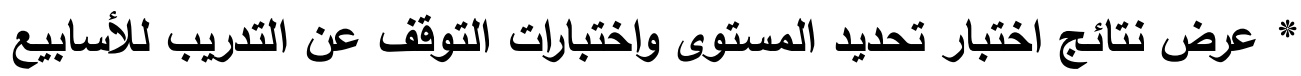
الأربعة للإرسال الواطئ القصير التئري

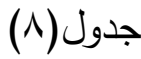

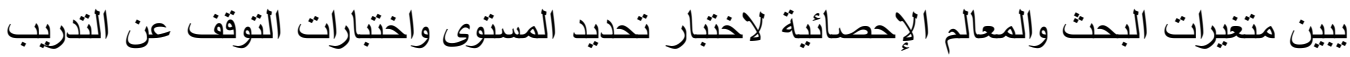
للأسابيع الأربعة للإِرسال الواطئ القصير لإلير

\begin{tabular}{|c|c|c|c|c|c|}
\hline اللسبة المئوية & قالمسوبة ت & الوسطين & $\varepsilon^{ \pm}$ & س & الكعالم الإحصائية \\
\hline \multirow{2}{*}{$\% \vee, o r$} & \multirow{2}{*}{$* \varepsilon, \cdot V$} & \multirow{2}{*}{$0, r \varepsilon$} & $r, 19$ & vi & تحديد المستوى \\
\hline & & & $r, 07$ & 70.74 & الأسبوع الأول \\
\hline \multirow[t]{2}{*}{$\% q, r q$} & \multirow[t]{2}{*}{ * * Or } & \multirow[t]{2}{*}{$7, \mathrm{TV}$} & $r, 19$ & vi & تحديد السستوى \\
\hline & & & 1,14 & 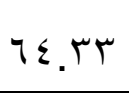 & الأسبوع الثاني \\
\hline \multirow{2}{*}{$\% \mid r, q)$} & \multirow{2}{*}{$* q, \cdot \varepsilon$} & \multirow{2}{*}{$9,1 \mathrm{~V}$} & $r, 19$ & vi & تحديد المستوى \\
\hline & & & $1, \varepsilon V$ & $\pi . \lambda r$ & الأسبوع الثالث \\
\hline \multirow[t]{2}{*}{$\% 17,7 \mathrm{~V}$} & \multirow[t]{2}{*}{$* 1 \leqslant, 9$} & \multirow{2}{*}{$11, \wedge \varepsilon$} & $r, 19$ & vi & تحديد المستوى \\
\hline & & & 1,97 & 09.17 & الأسبوع الرابع \\
\hline
\end{tabular}

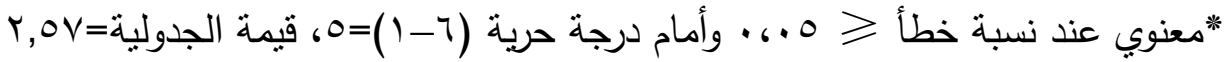

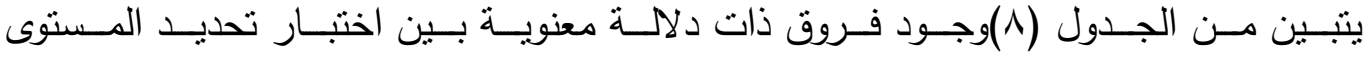

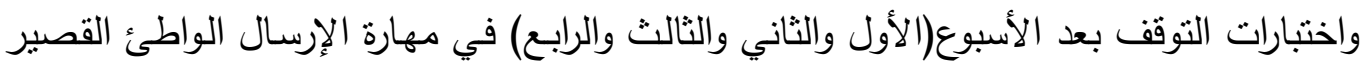

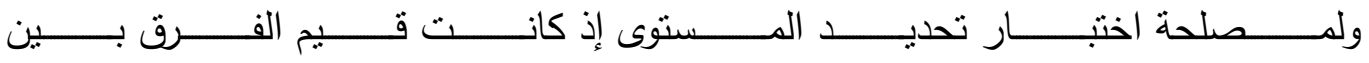

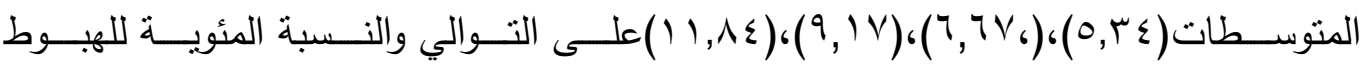

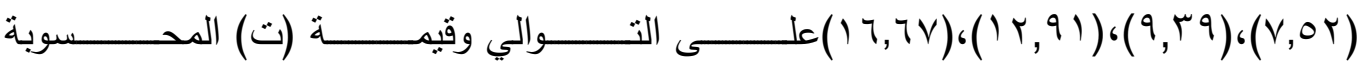




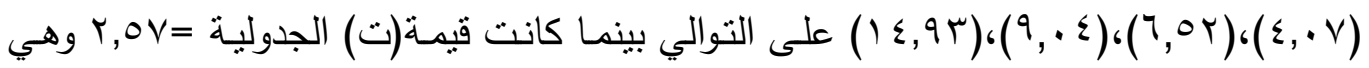

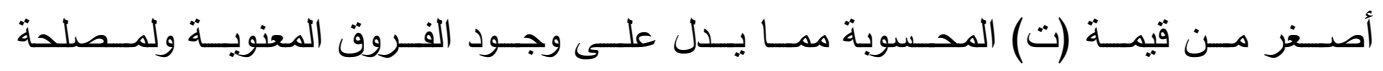
(اختبار تحديد المستوى).

عرض نتائج اختبار تعديد المستوى وإختبارات التوقف عن التدريب

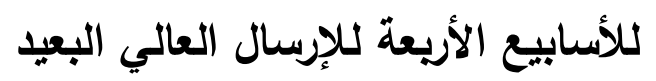

جدول(9)

يبين متغيرات البحث والمعاليم الإحصائية لاختبار تحديد المستوى واختبارات التوقف عن التدريب للأساييع الأربعة للإرسال العالي البعيد

\begin{tabular}{|c|c|c|c|c|c|}
\hline للالنبة المئوية & قالمحسوبة & الفرق بين & $\varepsilon^{ \pm}$ & س & آكعالم الإحصائية \\
\hline \multirow{2}{*}{ \%।r,Y } & \multirow{2}{*}{$* r, 9 \wedge$} & \multirow{2}{*}{$\varepsilon, I V$} & $r, 19$ & $r \varepsilon$ & تحديد المستوى \\
\hline & & & $r, 07$ & $r q, \wedge r$ & الأسبوع الأول \\
\hline \multirow{2}{*}{$\% 10, \mathrm{~V}}$. & \multirow{2}{*}{$* Y, r r$} & \multirow{2}{*}{$0, r \leqslant$} & $r, 19$ & $r \varepsilon$ & تحديد المستوى \\
\hline & & & 1,14 & Y^,TT & الأسبوع الثاني \\
\hline \multirow{2}{*}{$\% r^{\prime}, \cdot \wedge$} & \multirow{2}{*}{$* q, \cdot \varepsilon$} & \multirow{2}{*}{$V, I V$} & $r, 19$ & $r \varepsilon$ & تحديد المستوى \\
\hline & & & $1, \varepsilon V$ & $r\urcorner, \wedge r$ & الأسبوع الثالث \\
\hline \multirow{2}{*}{$\% \curlyvee \wedge, \varepsilon \varepsilon$} & \multirow{2}{*}{$* \wedge, 9$} & \multirow{2}{*}{$9,7 \vee$} & $r, 19$ & $r \varepsilon$ & تحديد المستوى \\
\hline & & & 1,97 & $r \leqslant, r T$ & الأسبوع الرابع \\
\hline
\end{tabular}

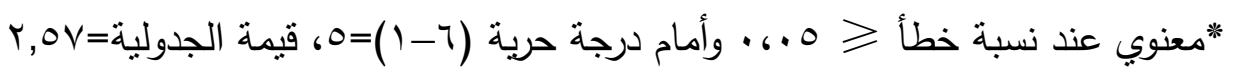

يتبين من الجدول (9)وجود فروق ذات دلالة معنويـة بين اختبار تحديد المستوى واختبارات

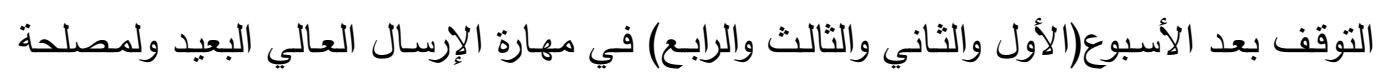

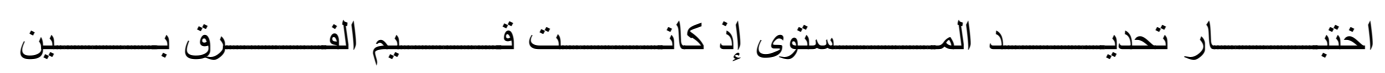

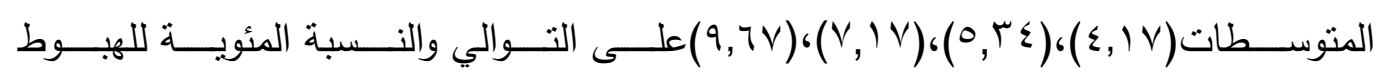

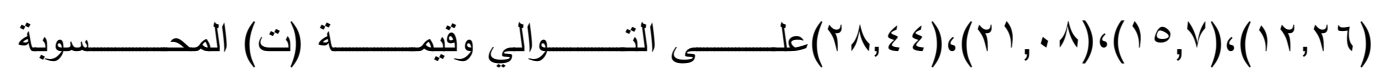




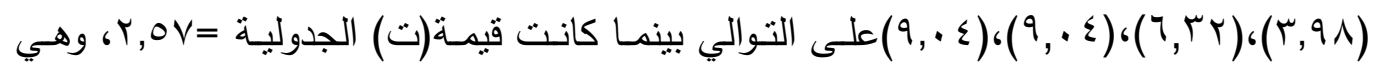

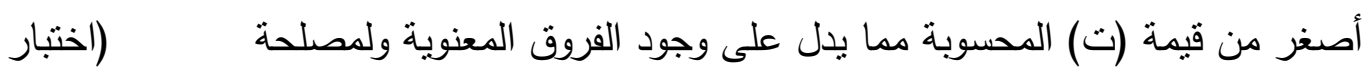

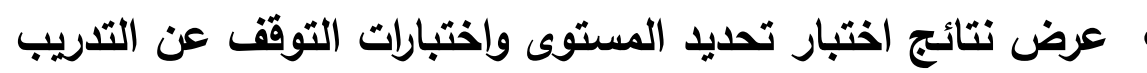
تحديد المستوى).

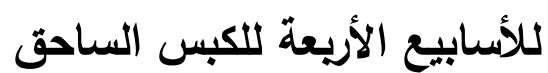

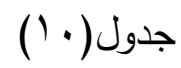

يبين متغيرات البحث والمعالم الإحصائية لاختبار تحديد المستوى واختبارات التوقف عن التدريب

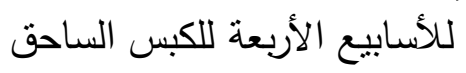

\begin{tabular}{|c|c|c|c|c|c|}
\hline اللسبة المئوية & قالمسمة ت & الفرق بين & $\varepsilon \pm$ & س & الكعالم الإحصائية \\
\hline \multirow{2}{*}{$\%\urcorner, \varepsilon}$. & \multirow{2}{*}{$*$} & \multirow{2}{*}{$0, r \mu$} & $r, \cdot \varepsilon$ & דr, & تحديد المستوى \\
\hline & & & $r, 07$ & $V V, \wedge r$ & الأسبوع الأول \\
\hline \multirow{2}{*}{$\% \wedge, 乏)$} & \multirow{2}{*}{$* \varepsilon, 01$} & \multirow{2}{*}{$V$} & $r, \cdot \varepsilon$ & דז,ו & تحديد المستوى \\
\hline & & & $r, r)$ & 17,17 & الأسبوع الثاني \\
\hline \multirow{2}{*}{$\% 11, .1$} & \multirow{2}{*}{$* 0, r q$} & \multirow{2}{*}{9,17} & $r, \cdot \varepsilon$ & דr,ו & تحديد المستوى \\
\hline & & & $r, 17$ & $V \varepsilon$ & الأسبوع الثالث \\
\hline \multirow{2}{*}{$\% 1 \leq, 7 r$} & \multirow{2}{*}{$* 0, \Sigma\rceil$} & \multirow{2}{*}{$1 Y, 17$} & $r, \cdot \varepsilon$ & Ar, & تحديد المستوى \\
\hline & & & $\varepsilon, \varepsilon V$ & vi & الأسبوع الرابع \\
\hline
\end{tabular}

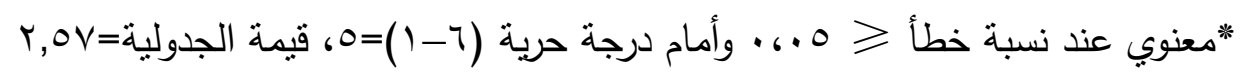

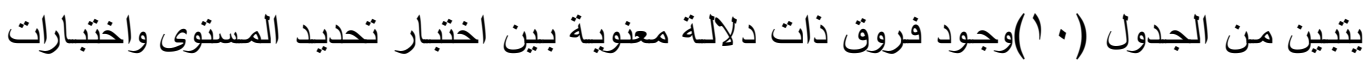

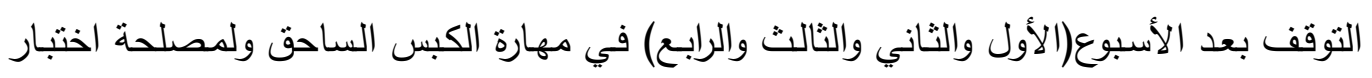

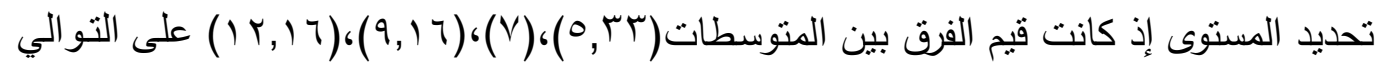

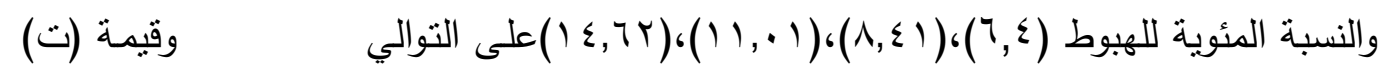

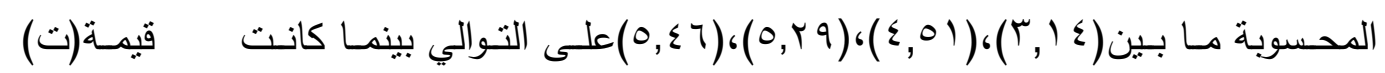


الجدولية = Y,OV., وهي أصغر من قيمة (ت) المحسوبة مما يدل على وجود الفروق المعنوية ولمصلحة (اختبار تحديد المستوى).

צ- ع باقشة النتائج:

* مناقشة نتائج اختبار تحديد المستوى واختبارات التوقف عن التدريب للأسابيع الأربعة لعناصر اللياقة البدنية الخاصة

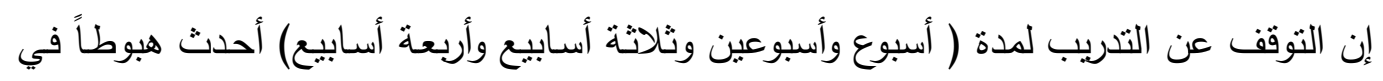

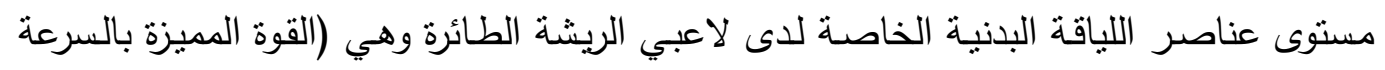

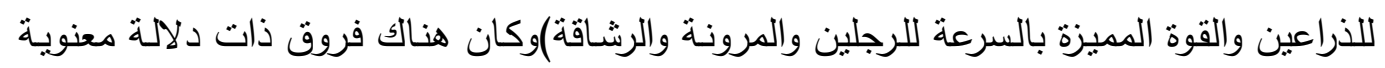
ولمصلحة الاختبار القبلي (اختبار تحديد المستوى).

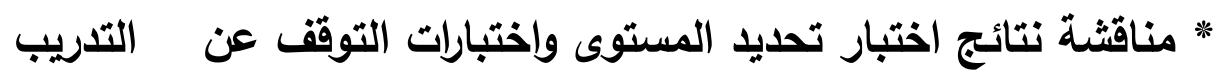
للأسابيع الأربعة للقوة المميزة بالسرعة للأراعين والرجلين

فبالنسبة للقوة المميزة بالسرعة فيعزو الباحث سبب الهبوط في المستوى إلى انخفاض مخزون

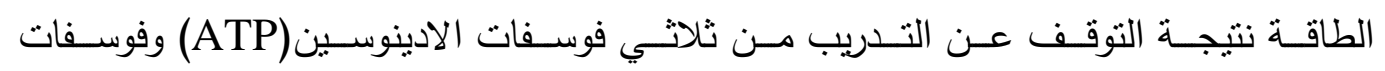

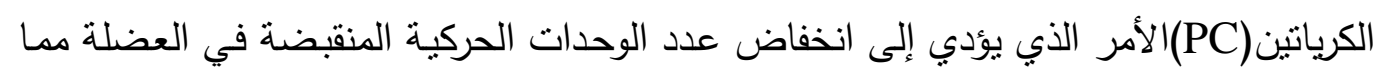
أدى إلى انخفاض مستوى القوة المميزة بالسرعة ويعزز هذا مـا أكده (Macdougall,1977)

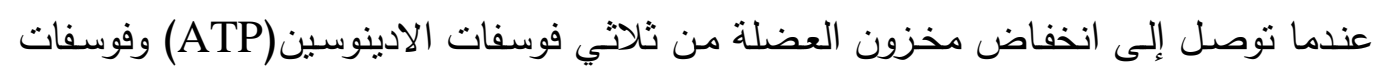

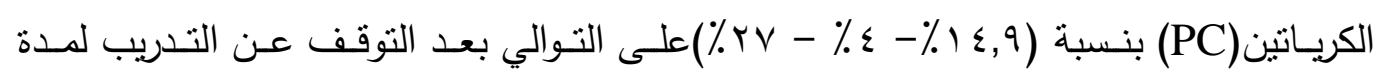

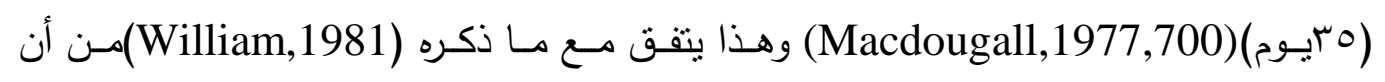
التوقف عن التدريب يؤدي إلى هبوط في مخزون الطاقة في العضلات (William,1981,269)

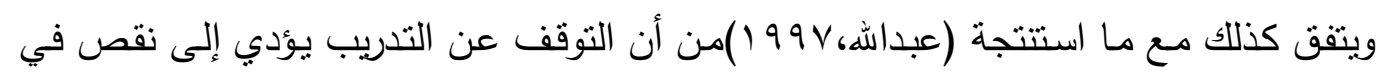

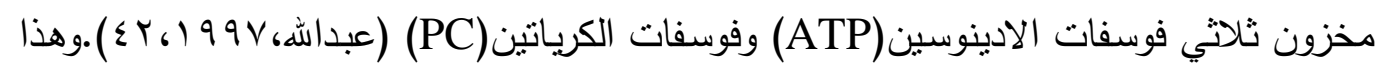

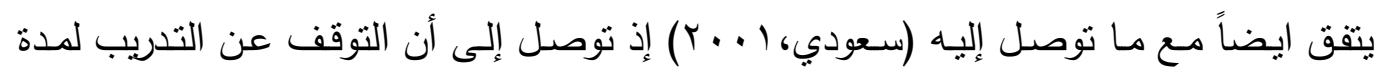

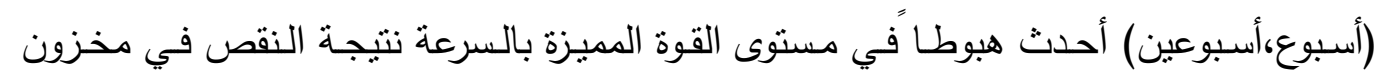

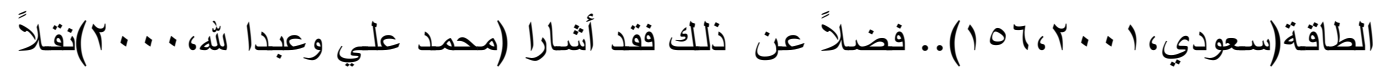

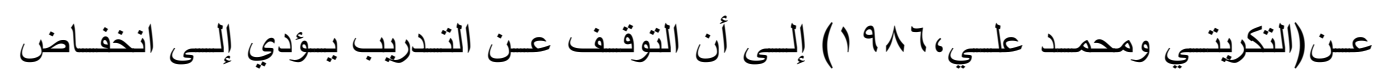
أنزيم(Pfk)وهو أنزيم هام في عملية تحلل السكر اللاهوائي(محمد علي وعبدا لله، ... . ب، 1 (1).). 


\section{* مناقثة نتائج اختبار تحديد المستوى واختبارات التوقف عن التدريب للأسابيع \\ الأربعة للمرونة}

أما فيما يخص عنصر المرونة فيعزو الباحث سبب الهبوط في المستوى إلى ما يأتي: ا-ـإن التوقف عن التدريب يؤدي إلى فقدان بعض مطاطية العضلة والأنسجة المحيطة بالمفصل

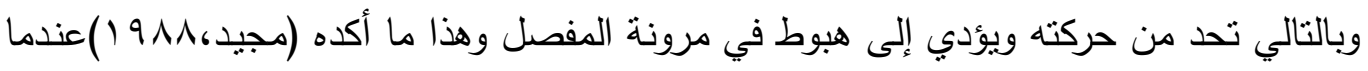
ذكر أن مطاطية العضلات المحيطة بالمفصل تحدد مداه الحركي وهي(العضلات) عامل مهم

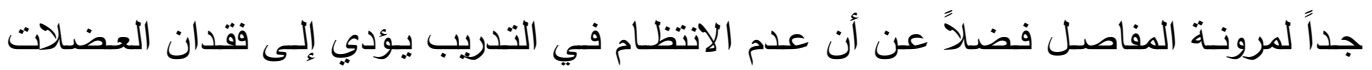

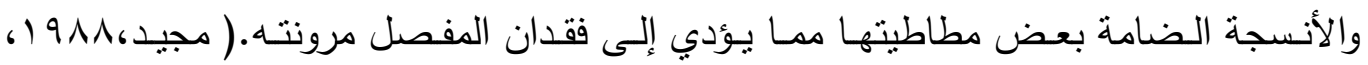

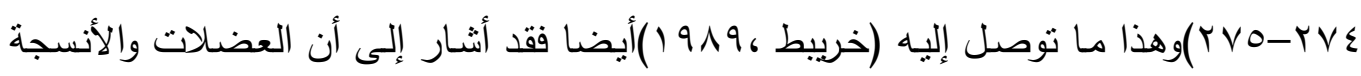
تفقد بعض مطاطيتها الطبيعية في حالة التوقف عن التدريب وذلك يقلل من مرونة المفاصل

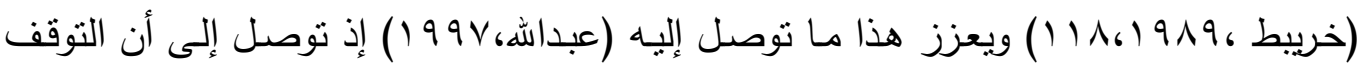

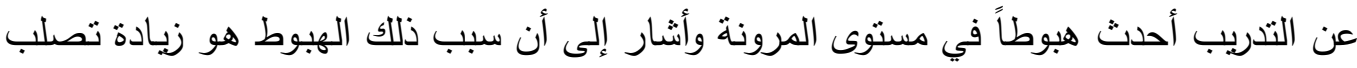

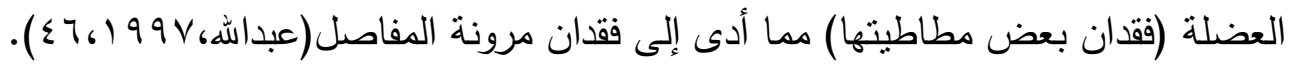
r-إن التوقف عن التدريب ربما يعمل على زيادة وزن اللاعب وذلك لزيادة خزن المواد الغذائية في الجسم بسبب عدم صرف طاقة مثل التي كان يصرفها اللاعب بالتدريب مما يؤدي إلى تراكم الشحوم في الجسم مما لله تأثير نسبي على المرونة ويؤكد هذا كذللك والحجار ،9194) إذ أكدا أن زيادة خزن المواد الغذائية الفائضة بالجسم تؤئدي إلى الانخفاض

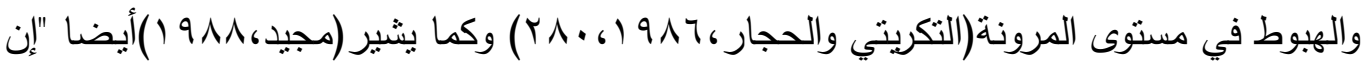

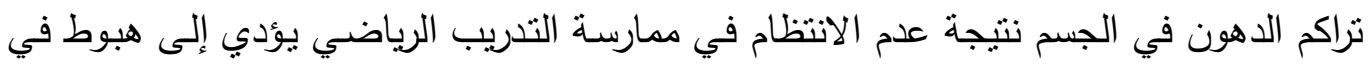

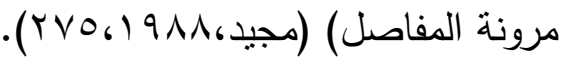


* مناقشة نتائج اختبار تحديد المستوى واختبارات التوقف عن التدريب للأسابيع الأربعة للرشاقة وبالنسبة إلى الرشاقة فيعزو الباحث سبب الهبوط في المستوى إلى ما يأتي:

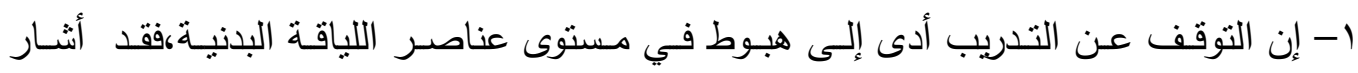

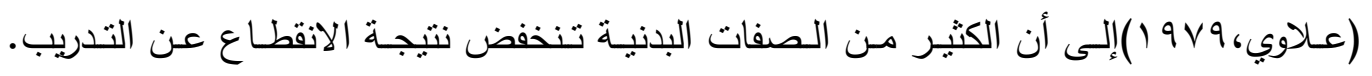

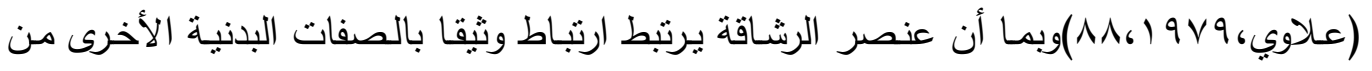

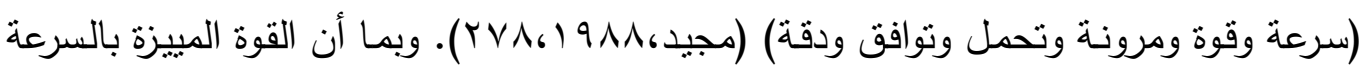

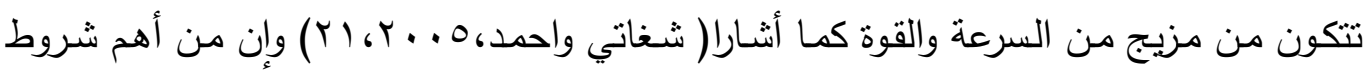

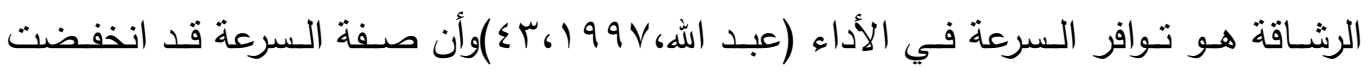
لانخفاض القوة المييزة بالسرعة التي تعد السرعة إحدى مكوناتها أدى إلى انخفاض الرشاقة.

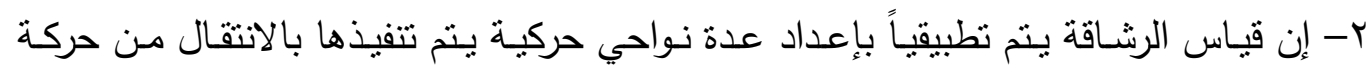

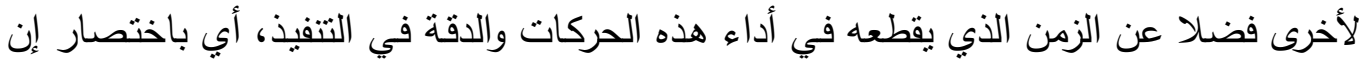

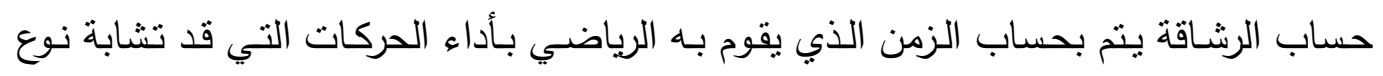

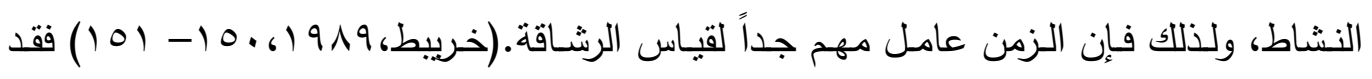

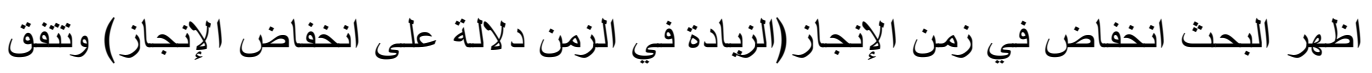

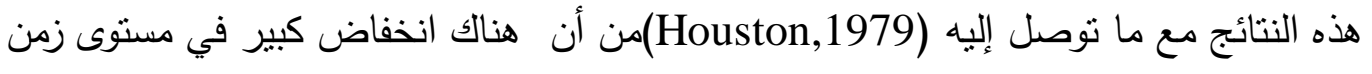
$-1 V \cdot)$

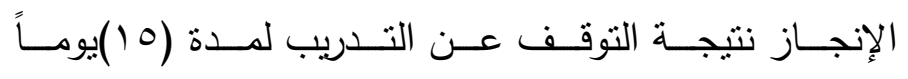

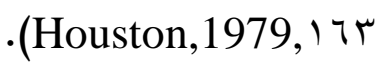

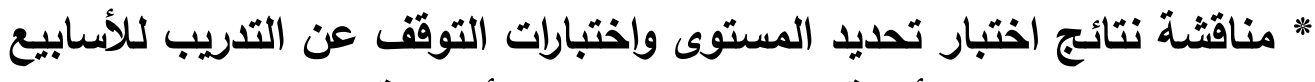

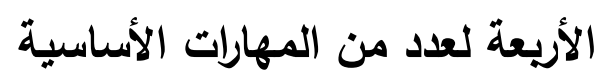

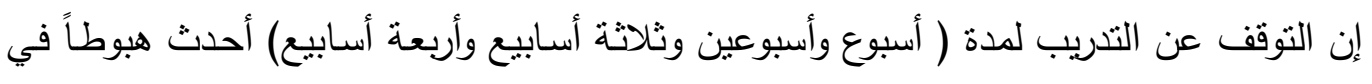
مسنوى المهارات الأساسية لدى لاعبي الريشة الطائرة وهي (الإرسال الواطئ القصير والإنئ الإرسال

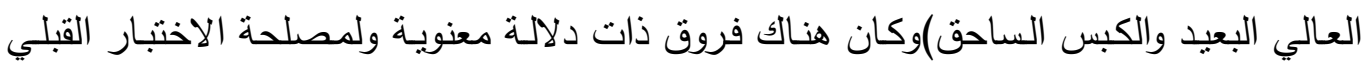
(تحديد المستوى).

ويعزو الباحث سبب ذلك الهبوط في مسنوى الأداء المهاري إلى الهبوط في مسنوى عناصر

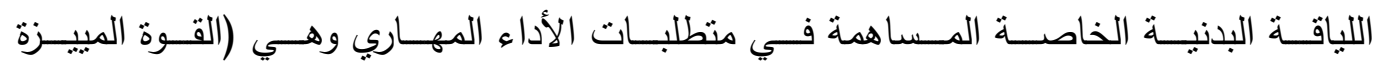

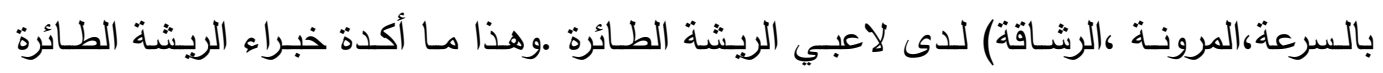
(Boomose,1996) ومطاولة...) هي التي تقرر الأداء المهاري للاعب إذ أن بينها ارتباط قوي وعلاقة وثيقة وان 


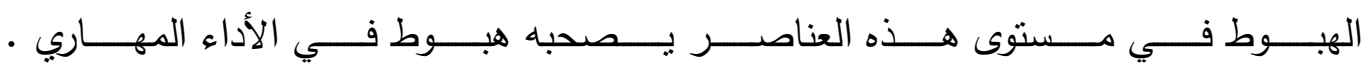
(Bo omose,1996,9-10).وكما أثنار (Roper,1995) إن اللاعب الذي يفقد عناصر اللياقة البننية فسوف تكون مهارته ضعيفة ولن يستطيع نوظيفها خلال المباراة وحتى يصبح لاعب

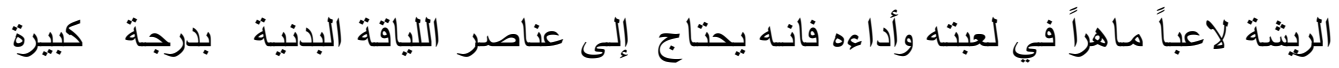

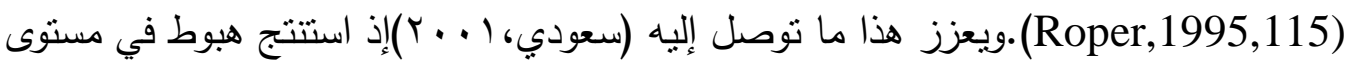
الأداء المهاري بسبب الهبوط في المسنوى البدني وعناصر اللباقة البدنية الخاصة المساهمة في

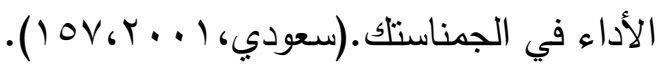

$$
\begin{aligned}
& \text { ه- الاستتناجات والتوصيات: } \\
& \text { ه-1 الاستنتاجات: }
\end{aligned}
$$

1- وجود فروق ذات دلالة معنوية في عناصر اللياقة البدنية الخاصة والمستوى المهاري نتيجة التوقف عن التدريب للأسابيع الأربعة.

r- كانت النسبة المئويـة لهبوط بعض عناصر اللياقة البدنيـة (القوة المييزة بالسرعة للذراعين والقوة المييزة بالسرعة للرجلين والمرونة) أسرع من النسبة المئوية لهبوط الرشاقة للأسابيع الأربعة. r- كانت النسبة المئوية لهبوط المهارات الأساسية (الإرسال الواطئ القصير والإرسال العالي البعيد والكبس الساحق) متقاربة في الأسابيع الأربعة. ع- كانت النسبية المئوية لهبوط القوة المييزة بالسرعة للذراعين من النسبة المئوية لباقي عناصر اللياقة البدنية للأسابيع الأربعة.

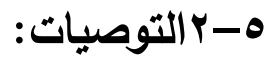

في ضوء النتائج التي تم النوصل إليها يوصي الباحث بما يأتي: 1- ضرورة مراعاة المدربين لظاهرة الهبوط في مستوى الكفاءة البدنية والمهارية والوظيفية نتيجة التوقف عن التدريب في أثناء تقنين الحمل التدريبي. r- ضـرورة قيام المدربين بالاختبـارات البدنيـة والمهاريـة والوظيفيـة بعد التوقف عن التدريب والعوده للتدريب للوقوف على نسبة الهبوط بشكل دقيق وبالتالي وضع برامج ندريبية لتطويرها بشكل منوازن وبما يتلائم ونسبة الهبوط. r- يفضل أن لا يتوقف اللاعب المصاب عن التدريب بشكل سلبي ويمكن العمل بالأجزاء غير

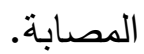
؟- إجراء دراسات على متغيرات بدنية ومهارية أخرى ولفترات زمنية مختلفة لدى لاعبي الريشة الطائرة بشكل خاص وفعاليات أخرى بشكل عام. 
1- اغا،أياد علي محمد،(V . . ب):تحليل التمايز لبعض المواصفات البدنية والمهارية والجسمية كدلالة للانتقاء والتتبؤ والتصنيف للاعبي الريشة الطائرة،رسالة ماجستير غير منشورة،كلية التربية

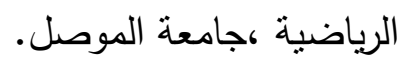
r- البكري،لؤي حسين شكر ( . . †): تأثير استخدام جدولة التمرين العشوائي والمجتمع في تعلم بعض المهارات الأساسية بالريشة الطائرة ،رسالة ماجستير غير منشورة ،كلية التربية الرياضية

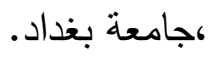

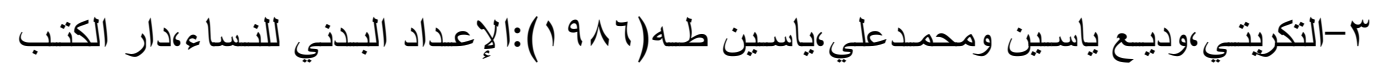

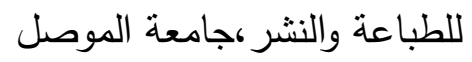

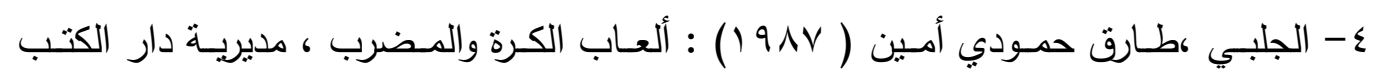
للطباعة والنشر ، جامعة الموصل.

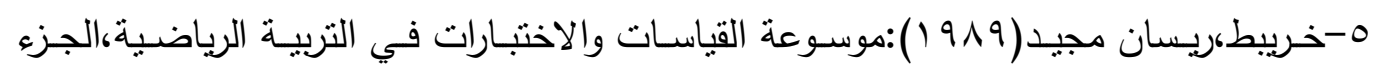
الأول،دار الكتب والوثائق،كلية التربية الرياضية،جامعة البصرة.

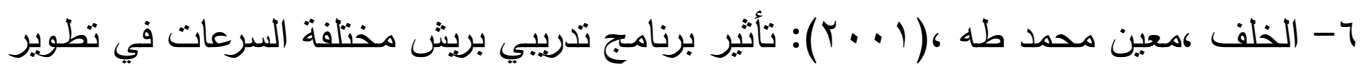
مهارات لعبة الريشة الطائرة ،أطروحة دكتوراه غير منشورة ،كلية التربية الرياضية ،جامعة بغداد

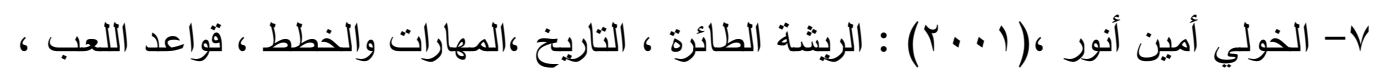
طب ، دار الفكر العربي ، القاهرة.

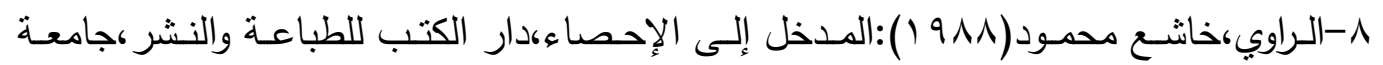

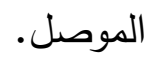

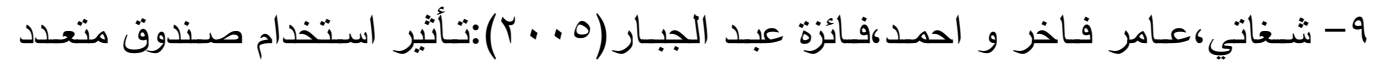
الارتفاعات لتنمية القوة المييزة بالسرعة على إنجاز الوثب الطويل،بحث منشور بمجلة التربية الرياضية، المجلد أ)، العدد الثاني ،جامعة ديالى.

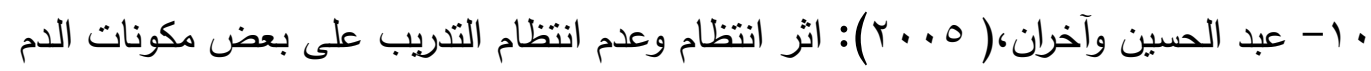

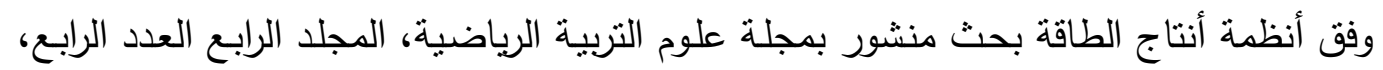

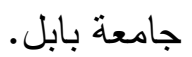

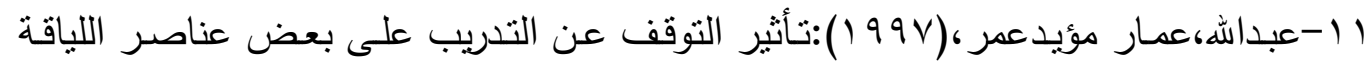

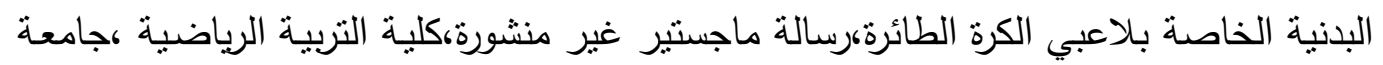

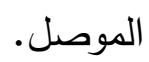

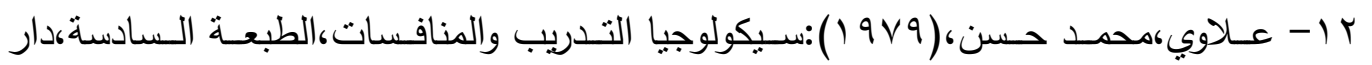

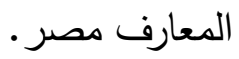




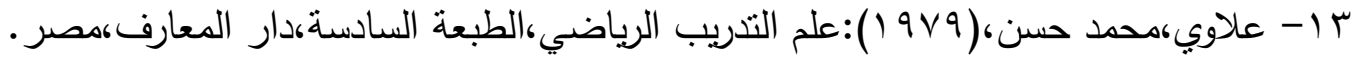

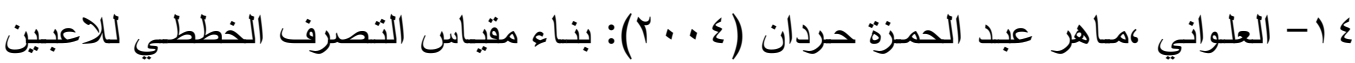

$$
\begin{aligned}
& \text { المتقدمين في بعض المهارات الأساسية بالريشة الطائرة في اللعب الفردي ، رسالة ماجستير غير } \\
& \text { منشورة ، كلية التربية الرياضية ، جامعة بابل. } \\
& 10 \text { - محمد علي،ياسين طه وعبد الله،أياد محمد(ب... ب):اثر التوقف عن ممارسة تدريبات فترية } \\
& \text { متتوعة لمدة ست أساييع على الإنجاز في عدو . عمتر،بحث منشور في مجلة الرافدين للعلوم } \\
& \text { الرياضية، المجلد الساد،العدد عشرون. } \\
& 17 \text { _ نصيف،عبد علي وحسين،قاسم حسن( • (91 ) ):قواعد التثريب الرياضي، الطبعة الأولى كدار }
\end{aligned}
$$

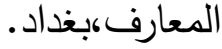

17.Boomose Gaard (1996):Phvsical Training for Badminton .In ternationl Badminton Federation . England.

18. Fox and mathews(1981): physical education and pysicologigcal_ba -sis. athletics, third edition philadelphia.

19.Houston, M.E. and others(1979): interrelationship between skeleal muscle ndaptation and peformance as stuied by detrning and re traning Asia. $\mathrm{Ph}$-ysiol-seand.

r. Peter Roper(1995) : The skills of the Games Badminton - UK -.

21. William.D. Mcardle and others(,1981): Exercise physiology energy nutrition-and human performance -lea and forbiger

22-Mac dougall, j.D, and others(1977):biochemical acla ptation of human skeletal mascle to heavy resistace training and immobilization.Jappl. ohycal,.

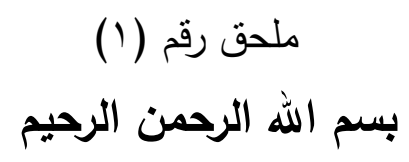


الخبير المحترم

في النية إجراء البحث الموسوم ( أثر التوقف عن التدريب في عدد من عناصر الياقة البذنية الخاصة ويعض المهارات الأساسية لاى لاعبي كرة الريشة الطائرة ) . ولفئة

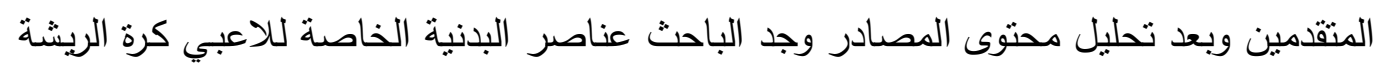

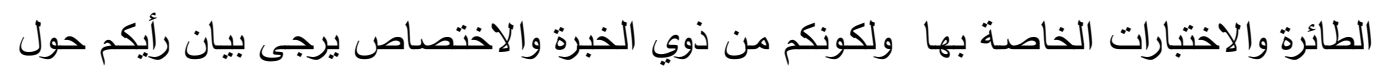

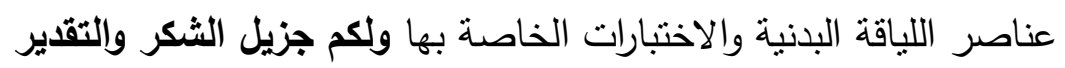

\begin{tabular}{|c|c|c|}
\hline الاختبارات & عناصر اللياقة البدنية الخاصة & $ت$ \\
\hline | الركض المرند 9 متر × م مرات & 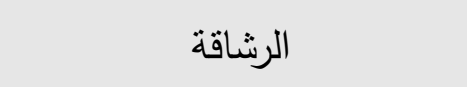 & 1 \\
\hline | ثني ومد الذراعين على جهاز المتوازي الواطئ خلال & القوة المميزة بالسرعة & $r$ \\
\hline | الوثب للأكمام أقصى مسافة خلال(ه ثا) & القوة المميزة بالسرعة للرجلين & $r$ \\
\hline ا اختبار نيلسون لسرعة الاستجابة & سرعة الاستجابة للذراعين & $\varepsilon$ \\
\hline |ثني الجذع للأمام والأسفل من الوقوف على الصندوق & 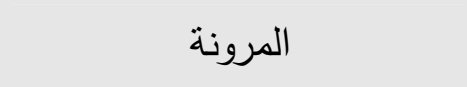 & $\bullet$ \\
\hline 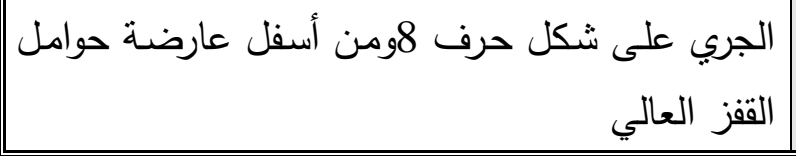 & التوافق بين العين واليد & 9 \\
\hline
\end{tabular}

\section{الباحث}

م.م عمار محمد خليل

ملاحظة / بمكن للسيد الخبير إضافة أي عنصر أو اختبار براه ملاثم

ملحق رقم (r)

بسم الله الرحمن الرحيم

$$
\text { الخبير المحترم }
$$


في النية إجراء البحث الموسوم ( أثر التوقف عن التدريب في عدد من عناصر

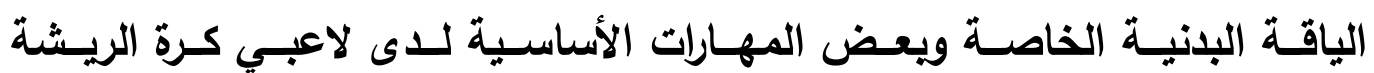
الطائرة ) • وبعد تحليل محتوى المصادر وجد الباحث المهارات الرئيسية والاختبارات الخاصة بها ولكونكم من ذوي الخبرة والاختصاص يرجى بيان رأيكم حول المهارات الرئيسية والاختبارات

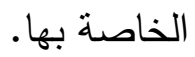

ولكم جزيل الشكر والتقدير

\begin{tabular}{|c|c|c|}
\hline الاختبارات الخاصة بها & المهارات الأساسية & 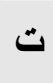 \\
\hline اختبار الإرسال العالي الطويل & الإرسال العالي الطويل & 1 \\
\hline اختبار الإرسال الواطئ القصير & الإرسال الواطئ القصير & r \\
\hline اختبار الضربة الأمامية & الضربة الأمامية & $r$ \\
\hline اختبار الضربة الخلفية & الضربة الخلفية & $\varepsilon$ \\
\hline اختبار ضربة الإبعاد الدفاعية & ضربة الإبعاد الدفاعية & • \\
\hline اختبار الضربة الساحقة & الضربة الساحقة & 9 \\
\hline
\end{tabular}

الباحث

م.م عمار محمد خليل

ملاحظة / يمكن للسيد الخبير إضافة أي عنصر أو اختبار يراه ملائم

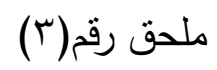

شكل رقم (1) 


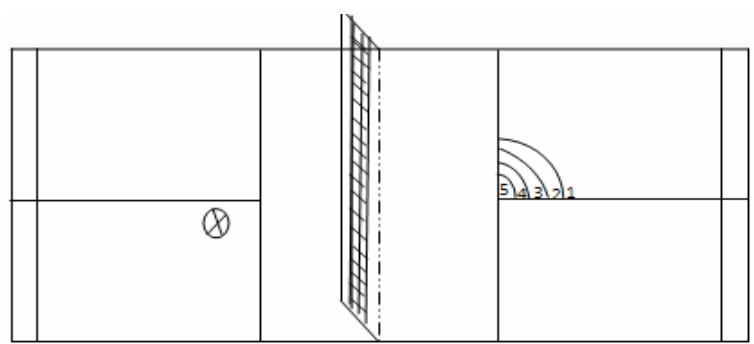

يوضح ملعب الريشة الطائرة مخطط بتصميم اختبار الإرسال القصير

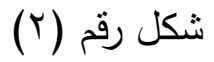

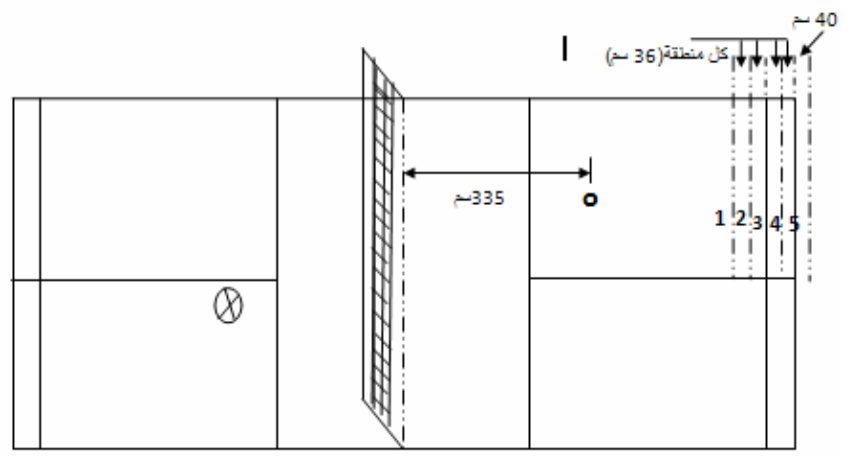

يوضح ملعب الريشة الطائرة مخطط بتصميم اختبار الإرسال العالي الطويل

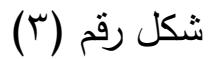

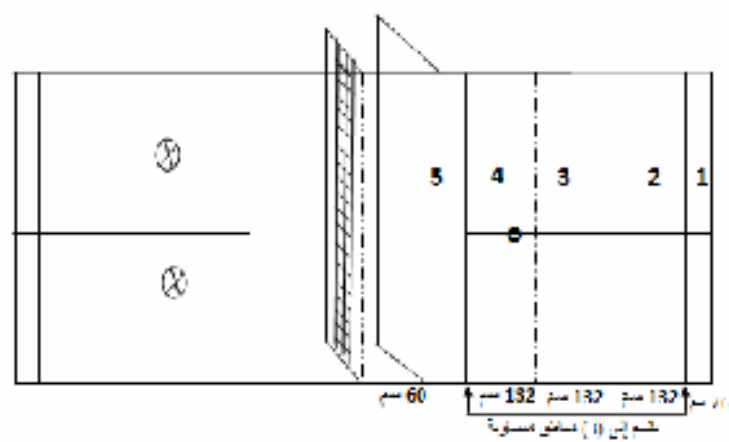

يوضح ملعب الريثة الطائرة مخطط بتصميم اختبار الضربة الساحقة

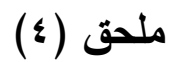

المنهاج التدريبي

ا ـ ينكون المنهاج التدريبي من (9) أسابيع مقسمة على (؟) دورات منوسطة . 
r. ت تكون كل دورة متوسطة من (r) أسابيع وبواقع (ץ) وحدات تدريبية أسبوعية.

r. يكون تموج درجة الحمل في كل دورة متوسطة (r: (1) .

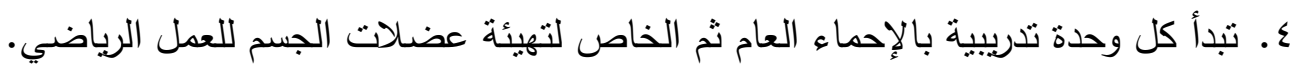

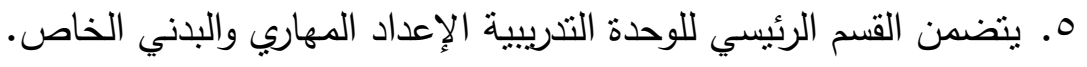

T. تنتهي كل وحدة تدريبية بتمرينات التهدئة .

\begin{tabular}{|c|c|c|c|c|c|c|c|c|c|}
\hline 1. & $\wedge$ & $V$ & 7 & 0 & $\varepsilon$ & $r$ & $r$ & 1 & درجة الحمل الأسابيع \\
\hline & & & & & & & & & أقصى \\
\hline & & & & & a & & & • & عالي \\
\hline 7 & & & & & & & & & متوسط \\
\hline
\end{tabular}

تموج درجة الحمل في الدورات المتوسطة الثلاث للمنهاج التدريبي

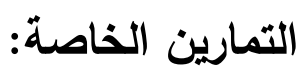

تمارين القوة المييزة بالسرعة:

-الحجل للجانب (• (1) ثانية

- الوقوف الذراع مثنية خلف الرأس وحاملة(دمبلص) مد وثثي الذراع للأعلى( • ( ) ثانية -الوقوف مسافة بين القدمين حمل ثقل خلف الرأس وفوق الرقبة ثني ومد الرجلين للجانب (· ( ) ثانية

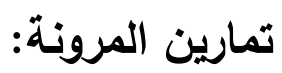

- انبطاح مع تتبيك الذراعين خلف الظهر ثم محاولة رفع الجذع (أقصى ما يمكن) - الوقوف حمل مضرب الريثة للأعلى ثم ميل الجذع للجانب(يمين ثم بسار ) (أقصى ما يمكن)

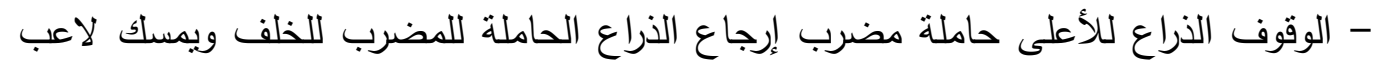

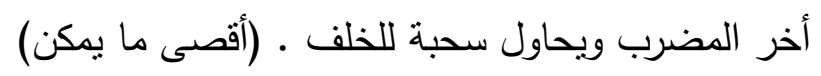

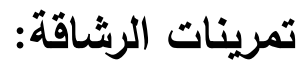


- الركض المرتد (بأقصى سرعة) - (برة)

- الجري المتعرج بين الأعلام (عشرة أعلام والجري من بينها ثم العودة سريعا) (بأقصى سرعة

- الجري واللف من حول الشواخص والرجوع واللف حول المركز بعد كل شاخص. (بأقصى سرعة) $\hat{v}$

$\hat{\jmath}$

(C)

$\uparrow$

$\Uparrow$ 